Research Article: New Research / Disorders of the Nervous System

\title{
Protein profiling of RGS6, a pleiotropic gene implicated in numerous neuropsychiatric disorders, reveals multi-isoformic expression and a novel brain-specific isoform
}

https://doi.org/10.1523/ENEURO.0379-21.2021

Cite as: eNeuro 2021; 10.1523/ENEURO.0379-21.2021

Received: 17 September 2021

Revised: 22 November 2021

Accepted: 24 November 2021

This Early Release article has been peer-reviewed and accepted, but has not been through the composition and copyediting processes. The final version may differ slightly in style or formatting and will contain links to any extended data.

Alerts: Sign up at www.eneuro.org/alerts to receive customized email alerts when the fully formatted version of this article is published.

Copyright @ 2021 Ahlers-Dannen et al.

This is an open-access article distributed under the terms of the Creative Commons Attribution 4.0 International license, which permits unrestricted use, distribution and reproduction in any medium provided that the original work is properly attributed. 
Title: Protein profiling of RGS6, a pleiotropic gene implicated in numerous neuropsychiatric disorders, reveals multi-isoformic expression and a novel brain-specific isoform

Abbreviated title: RGS6 brain-predominant multi-isoformic expression

Authors: KE Ahlers-Dannen*, Yang J*, MM Spicer, B Maity, A Stewart, JG Koland, RA Fisher *Denotes co-first authors

Affiliation during primary manuscript contribution:

Department of Neuroscience and Pharmacology, The Roy J and Lucille A Carver College of Medicine, University of lowa, lowa City, IA 52242

\section{Corresponding author:}

Rory A. Fisher

Email: rory-fisher@uiowa.edu

\section{Manuscript details:}

43 pages

9 figures, 7 extended data figures

0 tables, 0 supplemental tables

250 words for abstract

650 words for introduction

1500 words for discussion

Conflict of interest statement: The authors declare no competing financial interests.

\section{Acknowledgements:}

The work presented in this manuscript was supported by NIH CA161882, NIH AA025919, MJ Fox 11551.

Maity B and Stewart A, have moved to new institutions since producing the data they contributed to this manuscript. Maity B is now at the Center of Biomedical Research Lucknow, in India. Stewart A is now in the Department of Pharmacology at Florida Atlantic University in Boca Raton, FL (33431). 


\section{Abstract}

A metanalysis identified Regulator of G protein Signaling 6 (RGS6) as one of 23 loci with pleiotropic effects on four or more human psychiatric disorders. This finding is significant as it confirms/extends the findings of numerous other studies implicating RGS6 in CNS function and pathology. RGS6 is a highly conserved member of the RGS protein family whose cellular roles are likely affected by mRNA splicing and alternative domain inclusion/exclusion. Indeed, we previously identified multiple RGS6 splice variants predicted to produce 36 distinct protein isoforms containing either long (RGS6L) or short (RGS6S) N-terminal domains, an incomplete or intact GGL domain, and 9 alternative C-termini. Unfortunately, sequence similarities between the isoforms have made it difficult to confirm their individual existence and/or to determine their unique functions. Here, we developed 3 RGS6-specific antibodies that recognize all RGS6 protein isoforms (RGS6-fl), the N-terminus of RGS6L isoforms (RGS6-L), and an 18 amino acid alternate C-terminal sequence (RGS6-18). Using these antibodies, we demonstrate that RGS6L(+GGL) isoforms, predominating in both mouse (both sexes) CNS and peripheral tissues, are most highly expressed in the CNS. We further identify 3 novel RGS6 protein bands that are larger $(61,65$, and $69 \mathrm{kDa})$ than the ubiquitously expressed 53-57kDa RGS6L(+GGL) proteins. Importantly, we show that the $69 \mathrm{kDa}$ protein is a brain-specific dephospho- form of the $65 \mathrm{kDa}$ band, the first identified phosphorylated RGS6 isoform. Together, these data begin to define the functional significance behind the complexity of RGS6 gene processing and further clarifies RGS6's physiological roles by resolving tissue-specific RGS6 protein expression. 


\section{Significance Statement}

58 Psychiatric disorders are highly associated with polygenic variation. Consistent with this, a SNP

59 (rs2332700) in Regulator of G protein Signaling 6 (RGS6) is linked to autism spectrum disorder,

60 bipolar disorder, major depression, and schizophrenia. RGS6 is a highly conserved gene

61 whose complex alternative mRNA splicing produces numerous protein isoforms with high

62 sequence similarity, hindering their functional characterization. Therefore, while aberrant RGS6

63 signaling and/or expression have been linked to various neuropsychiatric disorders, it is unclear

64 which isoforms are important. This study functionally delineates between the various RGS6 isoforms within mouse. We demonstrate that RGS6 is most highly expressed in CNS, characterize the predominant isoforms, and identify a brain-specific RGS6 protein highly expressed in brain regions associated with various psychiatric disorders. 


\section{Introduction}

Psychiatric disorders are a leading cause of worldwide disability and affect more than $25 \%$ of the population (Collaborators, 2017, Kessler and Wang, 2008). Research in this area has noted that risk is highly associated with polygenic variation (Smoller et al., 2019, Sullivan et al., 2018). Furthermore, it is now clear that psychiatric disorders are not distinct and there is significant genetic overlap between them (Anttila et al., 2018, Consortium, 2013). Highlighting this point, a recent meta-analysis conducted by the Cross-Disorder Group of the Psychiatric Genomic Consortium (2019) of 232,964 psychiatric patients and 494,162 controls revealed 23 genetic loci with significant pleiotropic effects on $\geq 4 / 8$ disorders studied: anorexia nervosa, ADHD, autism spectrum disorder, bipolar disorder, major depression, OCD, schizophrenia, and Tourette syndrome.

One of the 23 pleiotropic genetic loci described was a SNP (rs2332700) in Regulator of G protein Signaling 6 (RGS6), previously identified in a GWAS of schizophrenic patients (Consortium, 2014), that was linked not only to schizophrenia, but also to autism spectrum disorder, bipolar disorder, and major depression. This finding is significant because of the study's magnitude and as it confirms/extends the findings of other human and animal studies implicating RGS6 in CNS function and pathology (Fig. 1). In particular, alterations in RGS6 signaling and/or expression have been associated with: alcohol use disorders (rs11621871) (Stewart et al., 2015, Chen et al., 2017), anxiety/depression (Stewart et al., 2014), Parkinson's disease (Bifsha et al., 2014, Luo et al., 2019, Petyuk et al., 2021), Alzheimer's disease (rs4899412) (Moon et al., 2015), motor coordination (Maity et al., 2012), adult hippocampal neurogenesis (Gao et al., 2020), as well as human cataracts, mental retardation, and microcephaly (c. 1369-1 G>C) (Chograni et al., 2014).

RGS proteins modulate the magnitude and duration of G protein-coupled receptor (GPCR) signaling by facilitating heterotrimeric G protein inactivation, a function bestowed by their RGS domain. RGS6 is a highly conserved (Fig. 2) member of the R7 subfamily, which 
modulates $\mathrm{Ga}_{i / 0}$ signaling and is distinguished by two additional domains, DEP and GGL, responsible for both membrane targeting and protein stability (Ross and Wilkie, 2000, Hooks et al., 2003). RGS6's cellular roles may also be affected by mRNA splicing and alternative domain inclusion/exclusion. Indeed, multiple RGS6 splice variants have been identified which are predicted to produce 36 distinct RGS6 protein isoforms containing either long (RGS6L) or short (RGS6S) N-terminal domains, an incomplete or intact GGL domain (-/+GGL), and 9 alternative C-termini (Fig. 3) (Chatterjee et al., 2003). Unfortunately, due to sequence similarity it has been difficult to confirm the existence of many of these isoforms or to determine their function. Therefore, while aberrant RGS6 signaling and/or expression have been linked to various neuropsychiatric disorders, it is unclear which RGS6 isoforms are important.

Adding further complexity are studies demonstrating RGS6 has critical physiological and pathophysiological functions outside the CNS as well. In the periphery RGS6 has been shown to: act as a critical tumor suppressor (Maity et al., 2011, Maity et al., 2013, Huang et al., 2011, Berman et al., 2004, Yang et al., 2016, Jiang et al., 2014, Luo et al., 2015, Dai et al., 2011), negatively modulate parasympathetic heart regulation (Yang et al., 2010, Wydeven et al., 2014, Posokhova et al., 2010), promote cardiovascular development (Chakravarti et al., 2017), associate with adiposity (Sibbel et al., 2011), and mediate heart-ischemic injury (Rorabaugh et al., 2017), doxorubicin-induced cardiac toxicity (Huang et al., 2011, Yang et al., 2013), as well as alcohol-induced cardiac, hepatic, and gastrointestinal damage (Stewart et al., 2015) (Fig. 1). Interestingly, not all of these peripheral functions (i.e. tumor suppression) rely on RGS6's ability to negatively regulate $\mathrm{Ga}_{\mathrm{i} / \mathrm{o}}$ (Maity et al., 2011).

As the list of RGS6's critical physiological and pathophysiological roles continues to grow, particularly with regards to neuropsychiatric disorders, it is imperative to perform a comprehensive analysis of RGS6 isoform expression. We hypothesize such an analysis will help to clarify the functional significance behind the complexity of RGS6 gene processing. 


\section{Materials and Methods}

\section{Mice}

We have previously described the generation of and genotyping methods for RGS6 ${ }^{-/-}$mice. (Yang et al., 2010). For these studies, RGS6 ${ }^{-/-}$mice were back-crossed onto the C57BL6 background for five generations. 3-month-old, male and female RGS6 ${ }^{+/+}$and RGS6 ${ }^{-l_{-}}$mice were used for the experiments described in the manuscript. All animal procedures described were approved by the University of lowa Institute for Animal Care and Use Committee.

\section{RGS6La1 conservation map}

NCBI's predicted protein sequence for human RGS6La1 (isoform 1-NP_001191245.1), the largest RGS6 isoform identified by Chatterjee et al. (2003) was BLASTed against the following taxids: Gorilla, Macaca, Papio, Soricidae, Mus, Oryctolagus, Sus, Camelus, Delphinus, Orcinus, Bos bovis, Ovis, Equus, Felis, Canis canis, Ailuropoda, Vulpes, Chiroptera, Loxodonta, Trichechus, Dasypodidae, and Didelphimorphia using NCBIs default settings. The sequence IDs with the highest amino acid conservation were placed in the MegAlign program (part of the DNASTAR Lasergene 12 Core Suit) and aligned using the Clustal W Method. This alignment was used to generate a circular map using the DNASTAR GenVision program.

\section{RGS6 structure homology modeling}

A structural model of RGS6La1 based on the RGS9/G $\beta_{5}$ complex structure (2PBI) (Cheever et al., 2008) was created using the Swiss-PdbViewer (Swiss Institute of Bioinformatics). Domains within the predicted RGS6La1 amino acid sequence that did not align with the RGS9/G $\beta_{5}$ complex were modeled with an in-house algorithm (clean.swiss.pl) created by the Elcock lab (University of lowa), which implements the Loopy program (Xiang et al., 2002). The model was visualized with VMD (Theoretical and Computational Biophysics Group, Beckman Institute, University of Illinois at Urbana-Champaign). 


\section{Cell culture and transfection for protein half-life assays}

HEK293T cells were plated in 12 well plates at $3.5 \times 10^{5}$ cells/well and were cultured in High Glucose Dulbecco's Modified Eagle's Medium (DMEM; Sigma-Aldrich) supplemented with 10\% fetal bovine serum (Gibco ${ }^{\circledR}$ 26140), 100 units $/ \mathrm{mL}$ penicillin (Gibco ${ }^{\circledR} 15140$ ), and $100 \mu \mathrm{g} / \mathrm{mL}$ streptomycin (Gibco $\left.{ }^{\circledR} 15140\right)$. 24hrs later cells were transiently co-transfected using the Lipofectamine 2000 system (ThermoFisher Scientific ${ }^{\circledR}$ 116680) with a pcDNA3.1-HA vector containing $G \beta_{5}\left(G \beta_{5}-H A\right)$ (gifted by Songhai Chen), a pEGFP vector containing R7BP (R7BPGFP) (gifted by Martemyanov, Scripps, FL), and a pcDNA3.1 vector containing RGS6 (1:1:2 ratio, total DNA $=1 \mu \mathrm{g} /$ well). Transfection media was exchanged for new supplemented DMEM media at $6 \mathrm{hrs}$ following transfection. 24hrs post-transfection, supplemented DMEM was removed, and cells were cultured in serum free supplemented DMEM containing $100 \mu \mathrm{M}$ cycloheximide (Sigma C6255) for 0, 2, 4, 6, 12, and 24hrs.

\section{Antibody generation}

Three different polyclonal RGS6 antibodies were used in this study. Antibodies to the Nterminal domain of RGS6L (RGS6-L) were generated with a synthetic peptide immunogen corresponding to residues 1-19 (MAQGSGDQRAVGVADPEESC-COOH) of RGS6L (Biosynthesis Inc) (Chatterjee et al., 2003). Antibodies to the unique splice forms of RGS6 that retain exon 18 sequences (RGS6-18) were generated (Biosynthesis Inc.) with a peptide immunogen corresponding to 14 amino acids in this region (-CKPESEQGRRTSLEK) (Chatterjee et al., 2003). Antibodies to full length RGS6L (RGS6-fl) were generated (Elmira Biologicals) to recombinant RGS6L following its expression, solubilization, and purification from inclusion bodies in bacteria. 


\section{Western Blot}

Cell Culture: Media was aspirated off cells and $100 \mu$ l of ice cold RIPA buffer (150mM NaCl, $1 \%$ NP-40, 0.5\% sodium deoxycholate, 0.1\% sodium dodecyl sulphate, 50mM Tris- $\mathrm{HCl}: \mathrm{pH} 8)$ containing protease (Roche 11836170001) and phosphatase (Sigma p5726) inhibitors was added to each well. Cells and RIPA were then placed in pre-chilled tubes, vortexed for 30sec, incubated on ice for $5 \mathrm{~min}$, and centrifuged at $8000 \mathrm{rpm}\left(4^{\circ} \mathrm{C}\right)$ for $10 \mathrm{~min}$. Supernatant was transferred to tubes containing 4x SDS PAGE Sample Buffer and boiled for 5 minutes before loading onto gels.

Tissues: Tissues were prepared for western blot analysis as previously described (Yang et al., 2016).

Western blots were probed with home-made rabbit anti-RGS6-specific antibodies (RGS6-L, RGS6-18, and RGS6-fl; 1:1,000-2,000), rabbit anti-Gß5 (a gift from Dr. William F Simonds, 1:1000 dilution)(Zhang et al., 1996), rabbit anti-RGS7 (a gift from Vladlen Z. Slepak, 1:1000 dilution)(Levay et al., 1999), rabbit anti-RGS9-2 (a gift from Steve Gold,1:1000 dilution)(Psifogeorgou et al., 2007, Psigfogeorgou et al., 2011), mouse-anti-RGS11 (a gift from Jason Chen, 1:1000 dilution)(Chen et al., 2010), as well as commercial mouse monoclonal antia-Tubulin (CalBiochem, CP06-100UG, 1:5000 dilution) and rabbit anti-actin (Sigma A2066, 1:1000), primary antibodies. LI-COR Odyssey goat anti-mouse (926-32220 and 926-32210) and goat anti-rabbit (926-32211 and 926-68071) secondary antibodies were used at a 1:10,000 dilution for protein visualization with the Odyssey system.

\section{Immunohistochemistry}

Mice were perfused with a saline solution at $1 \mathrm{~mL} / \mathrm{min}$ rate for $5 \mathrm{~min}$, followed by infusion of a freshly made fixative solution (4\% paraformaldehyde, $23 \mathrm{mM} \mathrm{NaH}_{2} \mathrm{PO}_{4}, 77 \mathrm{mM} \mathrm{Na}_{2} \mathrm{HPO}_{4}$ ) at 1 $\mathrm{ml} / \mathrm{min}$ rate for $15 \mathrm{~min}$. Tissues were collected and soaked in the fixative solution (4\% paraformaldehyde, $23 \mathrm{mM} \mathrm{NaH}_{2} \mathrm{PO}_{4}, 77 \mathrm{mM} \mathrm{Na}_{2} \mathrm{HPO}_{4}$ ) overnight. After fixation, tissues were 
embedded in paraffin and sectioned. Tissue sections of RGS6 ${ }^{+/+}$and $\mathrm{RGS6}^{-/-}$mice were processed to examine expression of RGS6 as we described previously (Maity et al., 2011). Briefly, sections were dewaxed in xylene, treated with a graded series of alcohol solutions, immersed in 3\% hydrogen peroxide to block endogenous peroxide activity, blocked with $5 \%$ bovine serum albumin and then incubated overnight at $4^{\circ} \mathrm{C}$ with rabbit anti-RGS6-fl antibody. Following washing $(3 \times 10 \mathrm{~min})$ in PBS, sections were incubated for $1 \mathrm{~h}$ at room temperature with peroxidase-conjugated secondary antibodies (Cell Signaling, 7074). A positive reaction was detected by exposure to stable diamin-obenzidene (General Biosciences Corporation) for 3min. The sections were counterstained in Harris hematoxylin and observed under the microscope. This is true for all tissues samples except heart. For mice hearts, frozen sections were blocked for 1 hour at $4^{\circ} \mathrm{C}$ in blocking buffer, containing $10 \%$ goat serum, $0.3 \%$ triton $\mathrm{X}-100,80.4 \mathrm{mM}$ $\mathrm{Na}_{2} \mathrm{HPO}_{4}, 19.0 \mathrm{mM} \mathrm{NaH}{ }_{2} \mathrm{PO}_{4}, \mathrm{pH} 7.4$, and then incubated overnight at $4^{\circ} \mathrm{C}$ with rabbit antiRGS6-fl antibody. Following washing $(3 \times 10 \mathrm{~min})$ in the blocking butter, sections were incubated for $1 \mathrm{~h}$ at room temperature with Alexa-conjugated secondary antibodies (Fisher scientific, A11011).

\section{Bioinformatic prediction of RGS6 phosphorylation sites}

Putative phosphorylation sites in RGS6La1 were identified using the Group-based Prediction System (GPS) 3.0 from Cuckoo Workgroup (Hubei, China). This software uses hierarchical grouping of protein kinases to identify possible kinase- or family-specific phosphorylation sites in each protein sequence based on a metric measuring similarity of the protein sequence to known phosphorylation site motifs. The software considers each specific serine/threonine/tyrosine residue and 7 amino acids up and downstream of that residue in generating a prediction score, a measure of the likelihood of peptide phosphorylation. In our analysis the threshold was set to high and predicted site/kinases were considered if their GPS prediction score was at least 1 above the cutoff value defined by the software $(\Delta$ Score $\geq 1)$. Phosphorylation sites and 
corresponding kinases meeting these criteria are listed in Fig. 7-1. Subsequently, a diagram depicting each putative RGS6 phosphorylation site and the corresponding kinase with the highest prediction score was constructed (Fig. 7A).

\section{Phosphatase/kinase assays}

Analysis of RGS6 phosphorylation and de-phosphorylation was assayed in RGS6 ${ }^{+/+}$and RGS6 ${ }^{-1-}$ whole brain tissue lysates. Tissues were homogenized in the absence of phosphatase inhibitor cocktail. Lysates were diluted to a final concentration of $2 \mu \mathrm{g} / \mu \mathrm{l}$ in $1 \mathrm{X}$ NEBuffer Pack for Protein MetalloPhosphatases (New England BioLabs; Ipswich, MA, USA). 100 units $\lambda$ phosphatase (New England BioLabs) were added to each reaction as indicated. For kinase assays, lysates were supplemented with $2 \mathrm{mM} \mathrm{ATP}$ and $1 \mathrm{mM} \mathrm{MgCl}_{2}$ required for enzyme activity, and with or without activators of PKA, PKC, or $\mathrm{Ca}^{2+}$-stimulated kinases as shown in Fig. 7D. 30mM NaF was added to reactions lacking $\lambda$ phosphatase and in kinase reactions to inhibit endogenous phosphatases. Reactions were incubated at $30^{\circ} \mathrm{C}$ for $20 \mathrm{~min}$ and terminated through the addition of $1 X$ sample buffer. Samples were subjected to SDS-PAGE and immunoblotting as described above.

\section{Experimental Design and Statistical Analysis}

All graphical data are expressed as mean \pm S.E.M. All sample sizes reported are based on conservative power analyses estimating $\beta=0.2(80 \%)$ with statistical significance being evaluated against $\alpha=0.05$. Effect sizes were estimated using Cohen's $d$ formulation prior to calculating power analyses. Significant differences within tissue expression data (Figs. 5B, 8A, 9A and Supp. Figs. 2-4) were analyzed via two-way ANOVA with Fisher's LSD post-hoc adjustment. Significant differences within immunoreactivity data (Figs. 7C and E) were also analyzed via two-way ANOVA with Fisher's LSD post-hoc adjustment. All data were analyzed using XLSTAT software. 


\section{Results}

Development and characterization of RGS6 antibodies confirms in vivo expression of RGS6L and identifies novel RGS6 protein bands

We previously cloned 36 distinct RGS6 mRNA splice-forms, from a human brain cDNA library, which were predicted to produce long (RGS6L) and short (RGS6S) RGS6 protein isoforms with an incomplete or intact GGL domain (-/+GGL) and 9 alternative C-termini (Fig. 3A) (Chatterjee et al., 2003). In this study, we endeavored to confirm the existence of these RGS6 isoforms in vivo. Therefore, we developed three antibodies, against: the whole RGS6L protein (RGS6-fl), the N-terminus of RGS6L protein isoforms (RGS6-L), and an alternative 18 amino acid sequence found in the C-terminus of 56\% of RGS6 isoforms (RGS6-18). Figure 3B shows the N-terminal sequence of RGS6 to which the RGS6-L antibody was generated and the lack of sequence conservation in this region with other R7 subfamily members. Figure $3 \mathrm{C}$ shows the alternatively spliced 18 amino acid sequence to which the RGS6-18 antibody was generated. Because the RGS6-fl antibody was generated to recombinant RGS6La2 this antibody likely targets multiple epitopes on RGS6 proteins. All antibodies were generated in rabbit against the human protein or its sequences that are conserved in mouse. We examined the ability of these three antibodies to detect native RGS6 protein isoforms by comparing western blots of whole brain lysates derived from RGS6 ${ }^{+/+}(\mathrm{WT})$ to RGS6 ${ }^{-/-}$(KO) mice (Yang et al., 2010) in order to identify RGS6-specific bands. Figure 4A shows representative western blots from our studies. Anti RGS6-fl recognizes three RGS6-specific bands identified by the magenta, blue and green arrows (Fig. 4A, left panel). The most abundant of these immunoreactive bands (magenta arrow) has a molecular weight of 53-57kDa, a size range corresponding to RGS6L protein isoforms containing the GGL domain, required for protein stabilization (RGS6L(+GGL), Fig. 4-1) (Chen et al., 2003, Cheever et al., 2008, Chatterjee et al., 2003). In addition, RGS6-fl recognizes $61 \mathrm{kDa}$ (blue arrow) and 69kDa (green arrow) bands that are larger than previously described RGS6 isoforms. We show below that the 69kDa isoform represents a novel brain- 
specific form of RGS6L (Fig. 5 and 8). Finally, the RGS6-fl antibody also detected a 58kD band (Fig. 4A, asterisk) in both RGS6 ${ }^{+/+}$and $\mathrm{RGS6}^{-/}$brain lysates, demonstrating this is not a RGS6 protein isoform. We confirmed by immunoblotting using an RGS7 antibody that this band represents RGS7 (not shown), the R7 subfamily member most closely related to RGS6. This was unsurprising given that RGS6-fl was generated to recombinant RGS6L.

Interestingly, while protein bands corresponding to RGS6L(+GGL) were readily apparent when using the RGS6-fl antibody isoforms lacking the GGL domain (RGS6L(-GGL), 49-52kDa, Fig. 4-1) were not (Fig. 4A, left panel) even with long blot exposures (not shown). Because the RGS6-fl antibody can detect RGS6L(-GGL) isoforms expressed in HEK 293 cells (Fig. 4B), the apparent absence of these isoforms in vivo is likely due to their relative instability compared to RGS6L(+GGL) isoforms, as suggested by cycloheximide chase experiments in HEK cells (Fig. 4C and D), and/or low abundance when compared to RGS6L(+GGL) isoforms. Interestingly, the RGS6-fl antibody also did not detect RGS6S(+/-GGL) proteins (34-41kDa, Fig. 4-1) in mouse brain (Fig. 4A, left panel), even though RGS6S transcripts were originally cloned from a human brain cDNA library (Chatterjee et al., 2003). As with the RGS6L(-GGL) isoforms, the inability to detect the RGS6S isoforms is not due to a lack of antibody specificity because antiRGS6-fl readily detects RGS6S(+/- GGL) proteins following expression in HEK293 cells (Fig. 4B). Therefore, lack of RGS6S isoforms in vivo may be due once again to their relative instability, suggested by cycloheximide chase experiments (Fig. 4C and D), and/or low their abundance when compared to RGS6L isoforms.

As the RGS6-fl antibody recognized not only RGS6, but also RGS7, a second antibody, RGS6-L, was generated against the first 19 amino acids (MAQGSGDQRAVGVADPEES) of the RGS6L isoforms, a sequence that shows minimal conservation across the R7 subfamily (Fig. 3B). The caveat to the RGS6-L antibody is that it does not detect RGS6S(+/-GGL) isoforms (Fig. 4B) which have a truncated N-terminus (Fig. 3A). However, given that the RGS6-fl antibody did not detect endogenous RGS6S isoforms in mouse brain (Fig. 4A, left panel), or in 
any other mouse peripheral tissues tested (data not shown), use of the RGS6-L antibody was deemed an acceptable alternative strategy. Subsequent western blot validation of the RGS6-L antibody revealed that it detects the same three RGS6 protein bands (magenta, green, and blue arrows) as theRGS6-fl antibody, but, unlike the RGS6-fl antibody, it does not detect RGS7 (asterisk, Fig. 4A, middle panel). Again, the most abundant immunoreactive band detected with both RGS6L and RGS6-fl antibodies is the 53-57 kD band (magenta arrow), corresponding to RGS6L(+GGL) isoforms (Fig. 4-1), followed by the brain-specific 69 kD band (green arrow) and then the $61 \mathrm{kD}$ band (blue arrow, Fig. 4A, left and middle panels). No other RGS6 proteins are detected by these two antibodies.

While the RGS6-L antibody eliminates detection of RGS7, it does not allow for easy delineation between the nine RGS6L(+GGL) isoforms, as they fall within a narrow molecular weight range (53-57kDa, Fig. 4-1). Therefore, a third antibody, RGS6-18, was generated against the alternative PESEQGRRTSLEKFTRSV amino acid sequence (Fig. 3C) encoded by exon 18 present near the C-terminus of 56\% of RGS6 isoforms (Fig. 3A, dark grey box starting at amino acid 456). As the RGS6-L and RGS6-18 antibodies were both made in rabbit, it was not possible to directly compare their banding pattern in a single blot. However, western blot analysis using RGS6-18 shows strong immunoreactivity of the 69kDa brain-specific band (green arrow) and the 53-57kDa band (magenta arrow) corresponding to RGS6L(+GGL) isoforms (Fig. 4A, right panel). The RGS6-18 antibody also recognizes RGS7 (asterisk, Fig. 4A, right panel) as a portion of the alternative amino acid sequence (RRTSLEKFTRSV) is present $(\leq 75 \%$ conservation) in a subset of RGS7 isoforms.

In summary, western blot analysis of RGS6 isoform expression in mouse brain tissue reveals that two of the antibodies, RGS6-fl and RGS6-18, also detect RGS6's closest evolutionary relative, RGS7. However, the RGS6-L antibody generated against the N-terminal sequence unique to RGS6L isoforms eliminates this problem. Further analysis revealed that while RGS6 proteins with molecular weights corresponding to RGS6L(+GGL) isoforms were 
readily detectable, RGS6L(-GGL) and RGS6S(+/-GGL) isoforms were not, possibly due to their relative instability or low abundance.

There are two remaining points of interest that arose from these initial cell culture and mouse tissue experiments. First, we discovered that overexpression of RGS6L(+/-GGL) and RGS6S(+/-GGL) transcripts in culture results in the expression of several protein bands, detected by the RGS6-fl antibody, that are not only equivalent in size but also smaller than the predicted protein molecular weights (Fig. 4B, yellow arrows and 4C,). Subsequent analysis of both transcript sequence and protein band molecular weights suggest that the small bands are likely RGS6 protein isoforms produced through alternative start sites. These alternative start sites are present in all four overexpressed transcripts, and thus similar low molecular weight bands are produced by each. As these alternative start sites exist in exons 8 and 10 (yellow stars, Fig. 4-2), present in all RGS6L and RGS6S transcripts, we would predict that these low molecular weight RGS6 proteins may be expressed in any tissue expressing RGS6. Second, western blots of mouse whole brain lysate revealed at least two additional RGS6 protein bands that were larger (61 and $69 \mathrm{kDa}$, blue and green arrows, respectively) than all previously described isoforms (Fig. 4A, left and middle panel). Both protein bands were detected by the RGS6-fl and RGS6-L antibodies, but only the 69kDa protein band was detected by the RGS618 antibody (Fig. 4A, right panel). From these data, the significance of these bands was uncertain. They are bona fide RGS6 protein isoforms as they were not detected in RGS6 ${ }^{-1}$ mice, but whether they represent novel RGS6 isoforms or post-translational modified proteins remained unclear.

\section{RGS6L(+GGL) is most highly expressed in CNS, but is also expressed in several}

\section{peripheral tissues}

As the RGS6-L antibody does not recognize RGS7, we used it to conduct a comprehensive western blot analysis of RGS6L expression in 31 tissues throughout the mouse body (Fig. 5). 
To standardize the westerns and allow for quantitative analysis of RGS6 expression across tissues, one $\mathrm{RGS6}^{+/+}$whole brain lysate was included as a control/constant denominator in every blot. These blots, and the subsequent densitometric analysis, revealed that RGS6L is significantly expressed in all CNS tissues analyzed, including, but not limited to the: cerebral cortex, olfactory bulb, midbrain, cerebellum, spinal cord, and retina (Fig. 5). Furthermore, RGS6L isoforms were also found at significant, albeit lower levels (Figs. 5 and 5-1) in two peripheral mouse tissues (heart and bladder). Finally, while statistical significance was not achieved due to small sample size, tissue variability, or low level of expression, RGS6 protein bands were also identified in lung, kidney, prostate, heart, omental fat, stomach, intestines, and breast (Fig. 5). This RGS6 expression profile corresponds well with previous reports describing the physiological and pathophysiological roles of RGS6 (Fig. 1).

To compliment this broad expression profile, we conducted an immunohistochemical analysis of RGS6 distribution (Fig. 6) in tissues found to express RGS6 protein bands via western (Fig. 5). The RGS6-fl antibody was used for this analysis, instead of the RGS6-L antibody, as it proved to stain tissues more reliably (data not shown). Furthermore, simultaneous staining of both $\mathrm{RGS6}^{-/-}$and RGS6 ${ }^{+/+}$tissues demonstrated that, unlike with western blot, the RGS6-fl antibody does not detect RGS7 proteins in intact tissues (Fig. 6). In the CNS, this analysis revealed that RGS6 is expressed ubiquitously across the cortical layers and confirmed what we had previously reported in the cerebellum (Maity et al., 2012), that RGS6 is expressed predominantly by neurons in the granule cell layer and Purkinje neurons. Likewise, there is a predominant neuronal expression of RGS6 in the spinal cord and olfactory bulb, as well as the midbrain, the latter finding confirming our previous evidence that RGS6 is expressed in midbrain dopaminergic neurons (Bifsha et al., 2014, Luo et al., 2019). Finally, in the retina, RGS6 proteins are highly expressed in ganglion cells as well as retinal pigmented epithelium and to a lesser extent in bipolar cells, rods, and cones. Moving to the periphery, robust RGS6 expression is detected throughout the walls of the heart, in omental fat cell 
plasma, and in epithelial cells of lung, bladder, breast, intestines, stomach, and kidney. A lower RGS6 expression is also seen in connective/muscular tissues adjacent to epithelial cells (Fig 6). Finally, an in-depth analysis of the RGS6 expression profile blots also elucidated the most prevalent RGS6L isoforms. Consistent with what had been seen earlier in whole brain lysates, the molecular weight of the protein bands observed suggested that RGS6L(+GGL) isoforms predominate (magenta arrow, 53-57kDa) in all tissues examined. Furthermore, it became apparent that, in addition to the large 61 and 69kDa bands (blue and green arrows, respectively), the RGS6-L antibody also detected a third novel protein band of $\sim 65 \mathrm{kDa}$ (orange arrow) in $\mathrm{RGS6}^{+/+}$and $\mathrm{RGS6}^{+/-}$, but not RGS6 ${ }^{-/-}$, mice. This band, while faint, was clearly visible in most CNS tissues blots with longer exposure times. Examination of the expression profile for all three bands revealed that while the $61 \mathrm{kDa}$ band is expressed in multiple tissues (brain, omental fat, breast, heart, stomach, intestine, lung, and bladder) the 65 and 69kDa bands are brain-specific (Fig. 5). Once again, the significance of these findings, whether these bands represented novel isoforms or post-translationally modified proteins, remained unclear. However, considering RGS6's association with various neuropsychiatric disorders, we were very intrigued by the discovery that two of these novel RGS6 protein bands were brain-specific.

\section{The novel, 65kDa brain-specific RGS6 is a phosphorylated protein}

Phosphorylation is a common form of post-translational modification. Indeed, the R7 family members, RGS7 and RGS9, have previously been shown to be phosphorylated (Benzing et al., 2002, Benzing et al., 1999, Sokal et al., 2003, Balasubramanian et al., 2001, Garzón et al., 2005, Ibi et al., 2011). There is also evidence from large-scale proteomic screens of the murine brain that supports the existence of RGS6 phospho-peptides with modifications on S244, S437, S459, and S490 of RGS6La1 (Safaei et al., 2011, Trinidad et al., 2012, Huttlin et al., 2010). Furthermore, group-based prediction of protein phosphorylation using GPS 3.0 software indicates that there are potentially 46 threonine, serine, and tyrosine residues in the RGS6La1 
protein that at serve as kinase substrates (Fig. 7A and Fig. 7-1). Several of these residues were also identified as sites of potential phosphorylation via a second, similar program, PhosphoNET, as well (Fig. 7-1). Therefore, we hypothesized that the large novel RGS6L protein bands may represent phospho-proteins and subsequently performed an in vitro phosphatase assay using protein lysates prepared from the whole $\mathrm{RGS6}^{+/+}$and $\mathrm{RGS6} 6^{-1-}$ mouse brains. This assay revealed that addition of $\lambda$ phosphatase to the lysate mixture eliminated the 65kDa RGS6L protein band, but not the 61 and 69kDa RGS6L species (Fig. 7B). This assay suggests that the $65 \mathrm{kDa}$ RGS6L protein band (orange arrow) represents a brain-specific phospho-protein.

Further experiments revealed that the 65kDa and 69kDa RGS6 isoforms represent interconvertible phospho- and dephospho-forms of RGS6, respectively. First, in support of this, analysis of the effects of phosphatase treatment on RGS6 isoforms revealed that phosphataseinduced loss of the 65kDa band was accompanied by an increase in the 69kDa band (Fig. 7C). This suggested that dephosphorylation of the $65 \mathrm{kDa}$ band did not result in its disappearance, but instead promoted an upward shift in its electrophoretic mobility to $69 \mathrm{kDa}$. Though phosphorylation does not change the electrophoretic mobility of most proteins, it can lead to an upward or downward shift in mobility depending upon the protein. Our results suggested that dephosphorylation of the 65kDa form produced an upward mobility shift. Noteworthy examples of proteins showing upward mobility shifts upon phosphorylation include cyclin-dependent kinase-2 (Cdk-2) (Gu et al., 1992), Cdk1 (Larochelle et al., 1998), and Cdk-7 (Garrett et al., 2001). To confirm this, we performed kinase reactions in brain extracts with ATP and various kinase activators. Figs. 7D and 7E show that incubation of extracts with ATP and $\mathrm{Ca}^{2+}$ promoted an increase in the 65kDa RGS6 band and a decrease in the 69kDa RGS6 band. These findings corroborate our evidence from Figs. 7B and 7C that the 65kDa band is a phosphorylated form of RGS6 and that dephosphorylation leads to an upward mobility shift to the $69 \mathrm{kDa}$ band. 
The predicted size of the largest RGS6 isoform shown in Fig. 7A is 56.5kDa (Fig. 4-1).

Our studies shown in Figs. 7B-7E show that the $53-57 \mathrm{kDa}$ and the $61 \mathrm{kDa}$ isoforms are not affected by phosphatase treatment or by incubation with ATP and kinase activators. Yet, all known members of the RGS6 protein family have some or all of the sequence elements shown in Fig. 7A. It is possible that the expected additional protein sequence in the novel brainspecific $69 \mathrm{kDa}$ possesses the site for $\mathrm{Ca}^{2+}$-dependent phosphorylation. Alternatively, it may possess sequence elements that confer substrate availability of sequences present in all/most RGS proteins shown in Fig. 7A. It is also possible that the 53-57kDa isoforms do not undergo mobility shifts upon phosphorylation/dephosphorylation and that the $61 \mathrm{kDA}$ isoform represents a novel RGS6 isoform whose transcript was not identified in the initial cloning effort (Chatterjee et al., 2003).

\section{The novel, 69kDa brain-specific RGS6 isoform is highly conserved and significantly} expressed in all regions of the brain analyzed

We found that the 69kDa dephospho- form of RGS6 was generally easier to detect and quantify in various brain regions than the $65 \mathrm{kDa}$ form, possibly due to dephosphorylation of the $65 \mathrm{kDa}$ isoform following sacrifice and brain dissection. The function of these isoforms in brain is unclear, but a cursory analysis hints at their importance. First, quantification of the $69 \mathrm{kDa}$ band demonstrates that it is significantly expressed, in all RGS6 ${ }^{+/+}$mouse brain tissues assayed (Figs. 8A and 8-1), although its expression level appears to be consistently lower than that of the 53-57kDa RGS6L protein isoforms (Figs. 7B and 7D). Given its exclusive expression in brain tissue we hereafter refer to the $69 \mathrm{kDa}$ isoform as RGS6B (and the 65kDa form as pRGS6B). Second, RGS6B appears to serve an important evolutionary function as western blot analysis reveals that it is not only expressed in mouse brain tissue, but also human brain tissue

(Fig. 8B, green arrow). 
RGS6 is the only R7 family member expressed in lung, omental fat, bladder, stomach, and intestine

As mentioned earlier, the western blot profile of RGS6L protein expression (Fig. 5) was consistent with the literature regarding RGS6's physiological and pathophysiological roles (Fig. 1). However, previous analysis of RGS mRNA expression profiles indicate that there is often overlap in the expression of several RGS's within a single tissue. For example, in situ hybridization (Gold et al., 1997) and RT-qPCR analyses (Larminie et al., 2004) demonstrated that the entire R7 RGS subfamily is expressed in the brain. Therefore, to determine whether, in tissues where it is expressed, RGS6 is the primary R7 subfamily member present we re-probed the RGS6-L western blots (Fig. 5) with an antibody against G $\beta_{5}$ (Fig. 9). G $\beta_{5}$ expression was found to be significantly higher in brain and retina vs other tissues (Fig. 9-1) as observed for RGS6L (Fig. 5-1).

$G \beta_{5}$ is an atypical $G \beta$ subunit that forms an obligate dimer with all R7 family members through interaction with their GGL domain (Fig. 3), which is structurally homologous to conventional $\mathrm{Gy}$ subunits. Interaction between $\mathrm{G} \beta_{5}$ and $\mathrm{R} 7$ family members is obligatory, loss of either interacting partner causes destabilization of the other (Chen et al., 2003). Emphasizing this point, in 2008 Cheever and colleagues solved the crystal structure of RGS9 and showed it in complex with $\mathrm{G} \beta_{5}$. Furthermore, this crystal structure revealed that the interaction between RGS9's GGL domain and G $\beta_{5}$ mirrors the orientation and interaction of the conventional Gßy dimer. This interaction orientation is believed to be maintained throughout the R7 subfamily, a hypothesis which is supported both by the solving of the crystal structure for RGS7, also in complex with $\mathrm{G} \beta_{5}$ (Patil et al., 2018), but also through structure homology modeling of RGS6L $\alpha 2$ (Fig. 9A, inset). Therefore, loss of $\mathrm{G}_{5}$ expression with RGS6 removal would indicate that RGS6 is the only R7 family member present in that tissue.

These analyses demonstrated that, while most tissues expressing RGS6 also express other R7 family members (G $\beta_{5}$ expression was maintained after RGS6 loss), there were some 
487 tissues, including: lung, bladder, stomach, intestine, and omental fat, where RGS6 appeared to 488 be the only R7 family member present ( $G \beta_{5}$ expression was completely lost with loss of RGS6, 489 Fig. 9A). Indeed, western blot analysis of a subset of the tissues showing a concomitant loss of 490 RGS6 and G $\beta_{5}$ expression (lung, omental fat, and bladder) using antibodies against individual 491 R7 family members (RGS's 7, 9-2, and 11) confirmed that RGS6 is the only R7 member 492 expressed there (Fig. 9B).

493 


\section{Discussion}

RGS6 pre-mRNA is subject to alternative splicing producing 36 unique transcripts each predicted to produce viable protein isoforms (Chatterjee et al., 2003). Despite knowing about this complex processing, sequence similarities have complicated the study of individual RGS6 isoforms. As such, most research implicating RGS6 in neuropsychiatric disorders or exploring its diverse peripheral roles have taken a global view of its function. This work provides the first comprehensive analysis of RGS6 isoform expression. Using three distinct antibodies generated against the whole RGS6L protein, the N-terminus of RGS6L isoforms, and an alternative amino acid sequence found in the C-terminus of 56\% of RGS6 isoforms, we have not only begun to define tissue-specific differences in RGS6 isoform expression but have also identified brainspecific RGS6 protein bands that appear to be phosphorylated/dephosphorylated only in CNS tissues.

\section{RGS6L(+GGL) isoforms are the most prevalent isoforms expressed in vivo}

Western blot analyses demonstrate that RGS6L(+GGL) isoforms predominate throughout the mouse body (Fig. 5, magenta arrow). As the nine possible RGS6L(+GGL) isoforms fall within a narrow molecular weight range (53-57kDa, Fig. 4-1) we were unable to definitively say which of these isoforms were present. However, using the RGS6-18 antibody, we conclude that, in the brain, at least some of the RGS6L(+GGL) isoforms include the amino acid sequence encoded by exon 18 (Fig. 4A, right panel). Furthermore, we hypothesize that RGS6La1 and RGS6La2, which differ only in the inclusion and exclusion, respectively, of the amino acid sequence encoded by exon 18 (Fig. 3), may represent the predominant brain RGS6L(+GGL) isoforms. This hypothesis is supported by the fact that RGS6La2 (GenbankTM AF073920) and RGS6La1 (GenbankTM AF107619) were the first RGS6L splice forms identified. These results suggest that RGS6La1 and RGS6La2 are expressed at relatively high levels compared to other 
RGS6L(+GGL) transcripts which were not identified until our subsequent cloning study (Chatterjee et al., 2003, Snow et al., 1999).

While the studies above suggest certain RGS6L(+GGL) isoforms may predominate due to relatively high mRNA transcript expression, this is likely not the only explanation for their prevalence. The R7 RGS protein subfamily is distinguished by two unique domains outside of the RGS domain: the DEP/DHEX domain and the GGL domain. Importantly, the GGL domain is required for interaction with $G \beta_{5}$, an atypical $G \beta$ subunit that forms an obligate dimer with all $R 7$ family members, promoting their stability (Chen et al., 2003). Consequently, RGS6L(+GGL) isoforms may be expected to be more stable (Fig. 4D) and thus expressed at higher levels relative to the RGS6L(-GGL) isoforms, which we previously showed do not bind Gß5 (Liu and Fisher, 2004).

Interestingly, as with the RGS6L(-GGL) isoforms, we did not identify RGS6 protein bands in the brain corresponding in size to RGS6S isoforms (Fig. 4A, Fig. 4-1), despite the fact their corresponding transcripts were originally cloned from a human brain cDNA library (Chatterjee et al., 2003). While this may be explained by low transcript abundance, it may also be caused by protein instability as suggested by our cycloheximide chase experiments (Fig. 4C and D). RGS6L and RGS6S protein isoforms arise via the use of alternative transcription start sites within the RGS6 gene sequence. Specially, while RGS6L protein isoforms are generated using a transcription start site upstream of exon 1 of the RGS6 gene, RGS6S isoforms arise via a transcription start site within intron 7. Therefore, RGS6S protein isoforms lack the first 140 amino acids present in the N-terminus of RGS6L isoforms, and therefore also lack the DEP/DHEX domain (Fig. 3A). The DEP/DHEX domain is known to promote membrane targeting of R7 family members by facilitating their interaction with two membrane proteins, the retina-specific RGS9 anchor protein (R9AP) and its close relative, R7 family binding protein (R7BP) which is ubiquitously expressed (Fig. 3A) (Hu and Wensel, 2002, Lishko et al., 2002, Martemyanov et al., 2003, Martemyanov et al., 2005, Drenan et al., 2005, Anderson et al., 2007, 
Patil et al., 2018). However, the DEP/DHEX domain may also facilitate the interaction between $\mathrm{G}_{5}$ and R7 family members (Cheever et al., 2008). Recent evidence supports a model whereby R9AP/R7BP strengthens the interaction between the DEP/DHEX and GGL domains with $\mathrm{G}_{5}$ promoting R7 RGS protein stabilization (Masuho et al., 2011, Patil et al., 2018). These findings are consistent with our cycloheximide chase experiments demonstrating that RGS6L isoforms are more stable than RGS6S isoforms (Fig. 4D).

\section{Identification of novel RGS6 protein bands}

We identified three RGS6 protein bands that were larger $(61,65$, and 69kDa) than any protein isoform predicted from our initial cloning effort $(\leq 57 \mathrm{kDa}$, Chatterjee et al., 2003). All three bands were RGS6L isoforms as they were recognized by the RGS6-L antibody (Fig. 4A and 5). Of these, the 65 and 69kDa bands appear to be brain-specific (Fig. 5) phospho- and dephospho forms of RGS6L, respectively. The $65 \mathrm{kDa}$ band, whose expression is reduced in the presence of $\lambda$ phosphatase and increased by a $\mathrm{Ca}^{2+}$-stimulated kinase activity, represents the first positively identified RGS6 phospho-protein (Figs. 7B-E). In contrast, the 69kDa RGS6L protein band is increased by $\lambda$ phosphatase (Fig. 7B) and decreased by $\mathrm{Ca}^{2+-}$ stimulated kinase activity

(Fig. 7E). Both the 61KDa and 69kDa RGS6 isoforms are much larger than predicted from any transcripts identified in our original cloning effort (Chatterjee et al., 2003), suggesting they may represent novel RGS6 isoforms. In support of this hypothesis, northern blot analyses conducted in human brain and peripheral tissues indicate that there is at least one transcript predominantly expressed in the CNS that is larger than the other RGS6 transcripts (which correspond in size to the RGS6L and RGS6S splice-forms) (Snow et al., 1999).

Of the novel RGS6 protein bands described above, the 69kDa RGS6B isoform is of particular interest. Importantly, we have shown that RGS6-specific inhibition of $\mathrm{Ga}_{\mathrm{i} / \mathrm{o}}$ modulates several CNS disorders for which RGS6 may be a novel therapeutic target. Remarkably, RGS6 ${ }^{-1-}$ mice have reduced anxiety/depression (Stewart et al., 2014), exhibit diminished alcohol 
seeking/reward (Stewart et al., 2015), and develop Parkinson's disease (Bifsha et al., 2014, Luo et al., 2019) (Fig. 1). Re-examination of the western blot data presented in these papers revealed that RGS6B is highly expressed in the brain regions affected by the CNS disorders described above, suggesting it plays a critical role in CNS pathology. Therefore, future studies should focus on identifying the transcript encoding RGS6B so that its function may be further explored. There are several pieces of evidence derived from this study that may aid in transcript identification. First, RGS6B is recognized by the RGS6-L antibody (Fig. 4A, middle panel, green arrow), indicating the transcript will contain exons 1-6, which encode the long Nterminus. Second, RGS6B is also recognized by the RGS6-18 antibody (Fig. 4A, right panel, green arrow), indicating that the transcript includes exon 18. Finally, RGS6B is present in both mouse and human (Fig. 8B), indicating it is highly conserved. Therefore, the sequence of the identified transcript must be derived from highly conserved regions within the RGS6 gene.

\section{Speculating on the possible effects of the rs2332700 SNP on RGS6 expression}

In reflecting on the present data and the recent meta-analysis (Consortium, 2019) which linked a SNP (rs2332700) in RGS6 to autism spectrum disorder, bipolar disorder, major depression, and schizophrenia, it becomes intriguing to speculate on the SNP's functionality. The rs2332700 SNP maps to intron 1 of the RGS6 gene and is associated with a G>C switch. Interestingly, this SNP is only found in primates (Fig. 5-2). While a functional role of this SNP has yet to be established, we hypothesize that it alters RGS6 expression. As RGS6L(+GGL) protein isoforms predominate (Fig. 5A, magenta arrow), we hypothesize that it is the physiological functions of these isoforms most highly impacted by the SNP. Interestingly, the RGS6L(+GGL) isoforms predominate not only in the CNS, but also in the periphery (Fig. 5), suggesting that the rs2332700 SNP may not only be linked to the psychological pathology of schizophrenia, autism spectrum disorder, bipolar disorder, and major depression, but also peripheral comorbidities associated with these diseases. In support of this hypothesis, we have 
demonstrated that global loss of RGS6 not only reduces CNS-associated alcohol seeking and reward behavior, in mice, but also protects against peripheral alcohol-mediated heart, liver, and gastrointestinal tract toxicity (Stewart et al., 2015).

Another intriguing piece of data from our current study is the discovery of a $69 \mathrm{kDa}$ form of RGS6 that is brain-specific (RGS6B). Although the functional nature of RGS6B is unknown, numerous western blot analyses conducted in this paper and others (Stewart et al., 2014, Stewart et al., 2015, Bifsha et al., 2014, Luo et al., 2019) demonstrate that it is highly expressed in several brain regions associated with numerous psychiatric disorders including, but not limited to, alcohol use disorders, anxiety/depression, and Parkinson's disease. In addition, our current data suggests that RGS6B shares several structurally similarities with the other predominant RGS6L(+GGL) isoforms (Fig. 4A). Therefore, it is intriguing to speculate that RGS6B expression may also be altered by the rs2332700 SNP. However, as RGS6B is not expressed in the periphery, we may surmise that alteration in its functional role would largely have psychological effects. 


\section{References}

ANDERSON, G. R., SEMENOV, A., SONG, J. H. \& MARTEMYANOV, K. A. 2007. The membrane anchor R7BP controls the proteolytic stability of the striatal specific RGS protein, RGS9-2. J Biol Chem, 282, 4772-81.

ANTTILA, V., BULIK-SULLIVAN, B., FINUCANE, H. K., WALTERS, R. K., BRAS, J., DUNCAN, L., ESCOTT-PRICE, V., FALCONE, G. J., GORMLEY, P., MALIK, R., PATSOPOULOS, N. A., RIPKE, S., WEI, Z., YU, D., LEE, P. H., TURLEY, P., GRENIER-BOLEY, B., CHOURAKI, V., KAMATANI, Y., BERR, C., LETENNEUR, L., HANNEQUIN, D., AMOUYEL, P., BOLAND, A., DELEUZE, J. F., DURON, E., VARDARAJAN, B. N., REITZ, C., GOATE, A. M., HUENTELMAN, M. J., KAMBOH, M. I., LARSON, E. B., ROGAEVA, E., ST GEORGE-HYSLOP, P., HAKONARSON, H., KUKULL, W. A., FARRER, L. A., BARNES, L. L., BEACH, T. G., DEMIRCI, F. Y., HEAD, E., HULETTE, C. M., JICHA, G. A., KAUWE, J. S. K., KAYE, J. A., LEVERENZ, J. B., LEVEY, A. I., LIEBERMAN, A. P., PANKRATZ, V. S., POON, W. W., QUINN, J. F., SAYKIN, A. J., SCHNEIDER, L. S., SMITH, A. G., SONNEN, J. A., STERN, R. A., VAN DEERLIN, V. M., VAN ELDIK, L. J., HAROLD, D., RUSSO, G., RUBINSZTEIN, D. C., BAYER, A., TSOLAKI, M., PROITSI, P., FOX, N. C., HAMPEL, H., OWEN, M. J., MEAD, S., PASSMORE, P., MORGAN, K., NÖTHEN, M. M., ROSSOR, M., LUPTON, M. K., HOFFMANN, P., KORNHUBER, J., LAWLOR, B., MCQUILLIN, A., AL-CHALABI, A., BIS, J. C., RUIZ, A., BOADA, M., SESHADRI, S., BEISER, A., RICE, K., VAN DER LEE, S. J., DE JAGER, P. L., GESCHWIND, D. H., RIEMENSCHNEIDER, M., RIEDEL-HELLER, S., ROTTER, J. I., RANSMAYR, G., HYMAN, B. T., CRUCHAGA, C., ALEGRET, M., WINSVOLD, B., PALTA, P., FARH, K. H., CUENCALEON, E., FURLOTTE, N., KURTH, T., et al. 2018. Analysis of shared heritability in common disorders of the brain. Science, 360.

BALASUBRAMANIAN, N., LEVAY, K., KEREN-RAIFMAN, T., FAUROBERT, E. \& SLEPAK, V. Z. 2001. Phosphorylation of the regulator of $G$ protein signaling RGS9-1 by protein kinase $A$ is a potential mechanism of light- and $\mathrm{Ca} 2+-$ mediated regulation of $\mathrm{G}$ protein function in photoreceptors. Biochemistry, 40, 12619-27.

BENZING, T., BRANDES, R., SELLIN, L., SCHERMER, B., LECKER, S., WALZ, G. \& KIM, E. 1999. Upregulation of RGS7 may contribute to tumor necrosis factor-induced changes in central nervous function. Nat Med, 5, 913-8.

BENZING, T., KÖTTGEN, M., JOHNSON, M., SCHERMER, B., ZENTGRAF, H., WALZ, G. \& KIM, E. 2002. Interaction of 14-3-3 protein with regulator of $\mathrm{G}$ protein signaling 7 is dynamically regulated by tumor necrosis factor-alpha. J Biol Chem, 277, 32954-62.

BERMAN, D. M., WANG, Y., LIU, Z., DONG, Q., BURKE, L. A., LIOTTA, L. A., FISHER, R. \& WU, X. 2004. A functional polymorphism in RGS6 modulates the risk of bladder cancer. Cancer Res, 64, 6820-6.

BIFSHA, P., YANG, J., FISHER, R. A. \& DROUIN, J. 2014. Rgs6 is required for adult maintenance of dopaminergic neurons in the ventral substantia nigra. PLoS Genet, 10, e1004863.

CHAKRAVARTI, B., YANG, J., AHLERS-DANNEN, K. E., LUO, Z., FLAHERTY, H. A., MEYERHOLZ, D. K., ANDERSON, M. E. \& FISHER, R. A. 2017. Essentiality of Regulator of G Protein Signaling 6 and Oxidized $\mathrm{Ca}(2+) /$ Calmodulin-Dependent Protein Kinase II in Notch Signaling and Cardiovascular Development. J Am Heart Assoc, 6.

CHATTERJEE, T. K., LIU, Z. \& FISHER, R. A. 2003. Human RGS6 gene structure, complex alternative splicing, and role of $\mathrm{N}$ terminus and $\mathrm{G}$ protein gamma-subunit-like (GGL) domain in subcellular localization of RGS6 splice variants. J Biol Chem, 278, 30261-71.

CHEEVER, M. L., SNYDER, J. T., GERSHBURG, S., SIDEROVSKI, D. P., HARDEN, T. K. \& SONDEK, J. 2008. Crystal structure of the multifunctional Gbeta5-RGS9 complex. Nat Struct Mol Biol, 15, 155-62.

CHEN, C. K., EVERSOLE-CIRE, P., ZHANG, H., MANCINO, V., CHEN, Y. J., HE, W., WENSEL, T. G. \& SIMON, M. I. 2003. Instability of GGL domain-containing RGS proteins in mice lacking the $\mathrm{G}$ protein betasubunit Gbeta5. Proc Natl Acad Sci U S A, 100, 6604-9. 
CHEN, F. S., SHIM, H., MORHARDT, D., DALLMAN, R., KRAHN, E., MCWHINNEY, L., RAO, A., GOLD, S. J. \& CHEN, C.-K. 2010. Functional redundancy of R7 RGS proteins in ON-bipolar cell dendrites. Investigative ophthalmology \& visual science, 51, 686-693.

CHEN, G., ZHANG, F., XUE, W., WU, R., XU, H., WANG, K. \& ZHU, J. 2017. An association study revealed substantial effects of dominance, epistasis and substance dependence co-morbidity on alcohol dependence symptom count. Addict Biol, 22, 1475-1485.

CHOGRANI, M., ALKURAYA, F. S., MAAZOUL, F., LARIANI, I. \& CHAABOUNI-BOUHAMED, H. 2014. RGS6: a novel gene associated with congenital cataract, mental retardation, and microcephaly in a Tunisian family. Invest Ophthalmol Vis Sci, 56, 1261-6.

COLLABORATORS, G. D. A. I. I. A. P. 2017. Global, regional, and national incidence, prevalence, and years lived with disability for 328 diseases and injuries for 195 countries, 1990-2016: a systematic analysis for the Global Burden of Disease Study 2016. Lancet, 390, 1211-1259.

CONSORTIUM, C.-D. G. O. T. P. G. 2013. Identification of risk loci with shared effects on five major psychiatric disorders: a genome-wide analysis. Lancet, 381, 1371-1379.

CONSORTIUM, C.-D. G. O. T. P. G. 2019. Genomic Relationships, Novel Loci, and Pleiotropic Mechanisms across Eight Psychiatric Disorders. Cell, 179, 1469-1482.e11.

CONSORTIUM, S. W. G. O. T. P. G. 2014. Biological insights from 108 schizophrenia-associated genetic loci. Nature, 511, 421-7.

DAI, J., GU, J., LU, C., LIN, J., STEWART, D., CHANG, D., ROTH, J. A. \& WU, X. 2011. Genetic variations in the regulator of $\mathrm{G}$-protein signaling genes are associated with survival in late-stage non-small cell lung cancer. PLoS One, 6, e21120.

DRENAN, R. M., DOUPNIK, C. A., BOYLE, M. P., MUGLIA, L. J., HUETTNER, J. E., LINDER, M. E. \& BLUMER, K. J. 2005. Palmitoylation regulates plasma membrane-nuclear shuttling of R7BP, a novel membrane anchor for the RGS7 family. J Cell Biol, 169, 623-33.

GAO, Y., SHEN, M., GONZALEZ, J. C., DONG, Q., KANNAN, S., HOANG, J. T., EISINGER, B. E., PANDEY, J., JAVADI, S., CHANG, Q., WANG, D., OVERSTREET-WADICHE, L. \& ZHAO, X. 2020. RGS6 Mediates Effects of Voluntary Running on Adult Hippocampal Neurogenesis. Cell Rep, 32, 108114.

GARRETT, S., BARTON, W. A., KNIGHTS, R., JIN, P., MORGAN, D. O. \& FISHER, R. P. 2001. Reciprocal activation by cyclin-dependent kinases 2 and 7 is directed by substrate specificity determinants outside the T loop. Mol Cell Biol, 21, 88-99.

GARZÓN, J., RODRÍGUEZ-MUÑOZ, M., LÓPEZ-FANDO, A. \& SÁNCHEZ-BLÁZQUEZ, P. 2005. Activation of mu-opioid receptors transfers control of Galpha subunits to the regulator of G-protein signaling RGS9-2: role in receptor desensitization. J Biol Chem, 280, 8951-60.

GOLD, S. J., NI, Y. G., DOHLMAN, H. G. \& NESTLER, E. J. 1997. Regulators of G-protein signaling (RGS) proteins: region-specific expression of nine subtypes in rat brain. J Neurosci, 17, 8024-37.

GU, Y., ROSENBLATT, J. \& MORGAN, D. O. 1992. Cell cycle regulation of CDK2 activity by phosphorylation of Thr160 and Tyr15. Embo j, 11, 3995-4005.

HOOKS, S. B., WALDO, G. L., CORBITT, J., BODOR, E. T., KRUMINS, A. M. \& HARDEN, T. K. 2003. RGS6, RGS7, RGS9, and RGS11 stimulate GTPase activity of Gi family G-proteins with differential selectivity and maximal activity. J Biol Chem, 278, 10087-93.

HU, G. \& WENSEL, T. G. 2002. R9AP, a membrane anchor for the photoreceptor GTPase accelerating protein, RGS9-1. Proc Natl Acad Sci U S A, 99, 9755-60.

HUANG, J., YANG, J., MAITY, B., MAYUZUMI, D. \& FISHER, R. A. 2011. Regulator of G protein signaling 6 mediates doxorubicin-induced ATM and p53 activation by a reactive oxygen species-dependent mechanism. Cancer Res, 71, 6310-9.

HUTTLIN, E. L., JEDRYCHOWSKI, M. P., ELIAS, J. E., GOSWAMI, T., RAD, R., BEAUSOLEIL, S. A., VILLÉN, J., HAAS, W., SOWA, M. E. \& GYGI, S. P. 2010. A tissue-specific atlas of mouse protein phosphorylation and expression. Cell, 143, 1174-89. 
IBI, M., MATSUNO, K., MATSUMOTO, M., SASAKI, M., NAKAGAWA, T., KATSUYAMA, M., IWATA, K., ZHANG, J., KANEKO, S. \& YABE-NISHIMURA, C. 2011. Involvement of NOX1/NADPH oxidase in morphine-induced analgesia and tolerance. J Neurosci, 31, 18094-103.

JIANG, N., XUE, R., BU, F., TONG, X., QIANG, J. \& LIU, R. 2014. Decreased RGS6 expression is associated with poor prognosis in pancreatic cancer patients. Int J Clin Exp Pathol, 7, 4120-7.

KESSLER, R. C. \& WANG, P. S. 2008. The descriptive epidemiology of commonly occurring mental disorders in the United States. Annu Rev Public Health, 29, 115-29.

LARMINIE, C., MURDOCK, P., WALHIN, J. P., DUCKWORTH, M., BLUMER, K. J., SCHEIDELER, M. A. \& GARNIER, M. 2004. Selective expression of regulators of G-protein signaling (RGS) in the human central nervous system. Brain Res Mol Brain Res, 122, 24-34.

LAROCHELLE, S., PANDUR, J., FISHER, R. P., SALZ, H. K. \& SUTER, B. 1998. Cdk7 is essential for mitosis and for in vivo Cdk-activating kinase activity. Genes Dev, 12, 370-81.

LEVAY, K., CABRERA, J. L., SATPAEV, D. K. \& SLEPAK, V. Z. 1999. Gß5 prevents the RGS7-Gao interaction through binding to a distinct Gy-like domain found in RGS7 and other RGS proteins. Proceedings of the National Academy of Sciences, 96, 2503-2507.

LISHKO, P. V., MARTEMYANOV, K. A., HOPP, J. A. \& ARSHAVSKY, V. Y. 2002. Specific binding of RGS9Gbeta $5 \mathrm{~L}$ to protein anchor in photoreceptor membranes greatly enhances its catalytic activity. $J$ Biol Chem, 277, 24376-81.

LIU, Z. \& FISHER, R. A. 2004. RGS6 interacts with DMAP1 and DNMT1 and inhibits DMAP1 transcriptional repressor activity. J Biol Chem, 279, 14120-8.

LUO, Y., QIN, S. L., YU, M. H., MU, Y. F., WANG, Z. S. \& ZHONG, M. 2015. Prognostic value of regulator of G-protein signaling 6 in colorectal cancer. Biomed Pharmacother, 76, 147-52.

LUO, Z., AHLERS-DANNEN, K. E., SPICER, M. M., YANG, J., ALBERICO, S., STEVENS, H. E., NARAYANAN, N. S. \& FISHER, R. A. 2019. Age-dependent nigral dopaminergic neurodegeneration and $\alpha$-synuclein accumulation in RGS6-deficient mice. JCI Insight, 5.

MAITY, B., STEWART, A., O'MALLEY, Y., ASKELAND, R. W., SUGG, S. L. \& FISHER, R. A. 2013. Regulator of $G$ protein signaling 6 is a novel suppressor of breast tumor initiation and progression. Carcinogenesis, 34, 1747-55.

MAITY, B., STEWART, A., YANG, J., LOO, L., SHEFF, D., SHEPHERD, A. J., MOHAPATRA, D. P. \& FISHER, R. A. 2012. Regulator of $G$ protein signaling 6 (RGS6) protein ensures coordination of motor movement by modulating GABAB receptor signaling. J Biol Chem, 287, 4972-81.

MAITY, B., YANG, J., HUANG, J., ASKELAND, R. W., BERA, S. \& FISHER, R. A. 2011. Regulator of G protein signaling 6 (RGS6) induces apoptosis via a mitochondrial-dependent pathway not involving its GTPase-activating protein activity. J Biol Chem, 286, 1409-19.

MARTEMYANOV, K. A., LISHKO, P. V., CALERO, N., KERESZTES, G., SOKOLOV, M., STRISSEL, K. J., LESKOV, I. B., HOPP, J. A., KOLESNIKOV, A. V., CHEN, C. K., LEM, J., HELLER, S., BURNS, M. E. \& ARSHAVSKY, V. Y. 2003. The DEP domain determines subcellular targeting of the GTPase activating protein RGS9 in vivo. $J$ Neurosci, 23, 10175-81.

MARTEMYANOV, K. A., YOO, P. J., SKIBA, N. P. \& ARSHAVSKY, V. Y. 2005. R7BP, a novel neuronal protein interacting with RGS proteins of the R7 family. J Biol Chem, 280, 5133-6.

MASUHO, I., WAKASUGI-MASUHO, H., POSOKHOVA, E. N., PATTON, J. R. \& MARTEMYANOV, K. A. 2011. Type $5 \mathrm{G}$ protein beta subunit (Gbeta5) controls the interaction of regulator of $\mathrm{G}$ protein signaling 9 (RGS9) with membrane anchors. J Biol Chem, 286, 21806-13.

MOON, S. W., DINOV, I. D., KIM, J., ZAMANYAN, A., HOBEL, S., THOMPSON, P. M. \& TOGA, A. W. 2015. Structural Neuroimaging Genetics Interactions in Alzheimer's Disease. J Alzheimers Dis, 48, 1051-63. 
PATIL, D. N., RANGARAJAN, E. S., NOVICK, S. J., PASCAL, B. D., KOJETIN, D. J., GRIFFIN, P. R., IZARD, T. \& MARTEMYANOV, K. A. 2018. Structural organization of a major neuronal G protein regulator, the RGS7-GB5-R7BP complex. Elife, 7.

PETYUK, V. A., YU, L., OLSON, H. M., YU, F., CLAIR, G., QIAN, W. J., SHULMAN, J. M. \& BENNETT, D. A. 2021. Proteomic Profiling of the Substantia Nigra to Identify Determinants of Lewy Body Pathology and Dopaminergic Neuronal Loss. J Proteome Res, 20, 2266-2282.

POSOKHOVA, E., WYDEVEN, N., ALLEN, K. L., WICKMAN, K. \& MARTEMYANOV, K. A. 2010. RGS6/Gß5 complex accelerates IKACh gating kinetics in atrial myocytes and modulates parasympathetic regulation of heart rate. Circ Res, 107, 1350-4.

PSIFOGEORGOU, K., PAPAKOSTA, P., RUSSO, S. J., NEVE, R. L., KARDASSIS, D., GOLD, S. J. \& ZACHARIOU, V. 2007. RGS9-2 is a negative modulator of mu-opioid receptor function. J Neurochem, 103, 61725.

PSIGFOGEORGOU, K., TERZI, D., PAPACHATZAKI, M. M., VARIDAKI, A., FERGUSON, D., GOLD, S. J. \& ZACHARIOU, V. 2011. A unique role of RGS9-2 in the striatum as a positive or negative regulator of opiate analgesia. Journal of Neuroscience, 31, 5617-5624.

RORABAUGH, B. R., CHAKRAVARTI, B., MABE, N. W., SEELEY, S. L., BUI, A. D., YANG, J., WATTS, S. W., NEUBIG, R. R. \& FISHER, R. A. 2017. Regulator of G Protein Signaling 6 Protects the Heart from Ischemic Injury. J Pharmacol Exp Ther, 360, 409-416.

ROSS, E. M. \& WILKIE, T. M. 2000. GTPase-activating proteins for heterotrimeric G proteins: regulators of G protein signaling (RGS) and RGS-like proteins. Annu Rev Biochem, 69, 795-827.

SAFAEI, J., MAŇUCH, J., GUPTA, A., STACHO, L. \& PELECH, S. 2011. Prediction of 492 human protein kinase substrate specificities. Proteome Sci, 9 Suppl 1, S6.

SIBBEL, S. P., TALBERT, M. E., BOWDEN, D. W., HAFFNER, S. M., TAYLOR, K. D., CHEN, Y. D., WAGENKNECHT, L. E., LANGEFELD, C. D. \& NORRIS, J. M. 2011. RGS6 variants are associated with dietary fat intake in Hispanics: the IRAS Family Study. Obesity (Silver Spring), 19, 1433-8.

SMOLLER, J. W., ANDREASSEN, O. A., EDENBERG, H. J., FARAONE, S. V., GLATT, S. J. \& KENDLER, K. S. 2019. Psychiatric genetics and the structure of psychopathology. Mol Psychiatry, 24, 409-420.

SNOW, B. E., BETTS, L., MANGION, J., SONDEK, J. \& SIDEROVSKI, D. P. 1999. Fidelity of G protein betasubunit association by the $\mathrm{G}$ protein gamma-subunit-like domains of RGS6, RGS7, and RGS11. Proc Natl Acad Sci U S A, 96, 6489-94.

SOKAL, I., HU, G., LIANG, Y., MAO, M., WENSEL, T. G. \& PALCZEWSKI, K. 2003. Identification of protein kinase $C$ isozymes responsible for the phosphorylation of photoreceptor-specific RGS9-1 at Ser475. J Biol Chem, 278, 8316-25.

STEWART, A., MAITY, B., ANDEREGG, S. P., ALLAMARGOT, C., YANG, J. \& FISHER, R. A. 2015. Regulator of $G$ protein signaling 6 is a critical mediator of both reward-related behavioral and pathological responses to alcohol. Proc Natl Acad Sci U S A, 112, E786-95.

STEWART, A., MAITY, B., WUNSCH, A. M., MENG, F., WU, Q., WEMMIE, J. A. \& FISHER, R. A. 2014. Regulator of G-protein signaling 6 (RGS6) promotes anxiety and depression by attenuating serotonin-mediated activation of the 5-HT(1A) receptor-adenylyl cyclase axis. Faseb j, 28, 173544.

SULLIVAN, P. F., AGRAWAL, A., BULIK, C. M., ANDREASSEN, O. A., B $\varnothing$ RGLUM, A. D., BREEN, G., CICHON, S., EDENBERG, H. J., FARAONE, S. V., GELERNTER, J., MATHEWS, C. A., NIEVERGELT, C. M., SMOLLER, J. W. \& O'DONOVAN, M. C. 2018. Psychiatric Genomics: An Update and an Agenda. Am J Psychiatry, 175, 15-27.

TRINIDAD, J. C., BARKAN, D. T., GULLEDGE, B. F., THALHAMMER, A., SALI, A., SCHOEPFER, R. \& BURLINGAME, A. L. 2012. Global identification and characterization of both O-GlcNAcylation and phosphorylation at the murine synapse. Mol Cell Proteomics, 11, 215-29. 
804

805

806

807

808

809

810

811

812

813

814

815

816

817

818

819

820

821

822

823
WYDEVEN, N., POSOKHOVA, E., XIA, Z., MARTEMYANOV, K. A. \& WICKMAN, K. 2014. RGS6, but not RGS4, is the dominant regulator of G protein signaling (RGS) modulator of the parasympathetic regulation of mouse heart rate. J Biol Chem, 289, 2440-9.

XIANG, Z., SOTO, C. S. \& HONIG, B. 2002. Evaluating conformational free energies: the colony energy and its application to the problem of loop prediction. Proc Natl Acad Sci U S A, 99, 7432-7.

YANG, J., HUANG, J., MAITY, B., GAO, Z., LORCA, R. A., GUDMUNDSSON, H., LI, J., STEWART, A., SWAMINATHAN, P. D., IBEAWUCHI, S. R., SHEPHERD, A., CHEN, C. K., KUTSCHKE, W., MOHLER, P. J., MOHAPATRA, D. P., ANDERSON, M. E. \& FISHER, R. A. 2010. RGS6, a modulator of parasympathetic activation in heart. Circ Res, 107, 1345-9.

YANG, J., MAITY, B., HUANG, J., GAO, Z., STEWART, A., WEISS, R. M., ANDERSON, M. E. \& FISHER, R. A. 2013. G-protein inactivator RGS6 mediates myocardial cell apoptosis and cardiomyopathy caused by doxorubicin. Cancer Res, 73, 1662-7.

YANG, J., PLATT, L. T., MAITY, B., AHLERS, K. E., LUO, Z., LIN, Z., CHAKRAVARTI, B., IBEAWUCHI, S. R., ASKELAND, R. W., BONDARUK, J., CZERNIAK, B. A. \& FISHER, R. A. 2016. RGS6 is an essential tumor suppressor that prevents bladder carcinogenesis by promoting $\mathrm{p} 53$ activation and DNMT1 downregulation. Oncotarget, 7, 69159-69172.

ZHANG, S., COSO, O. A., LEE, C., GUTKIND, J. S. \& SIMONDS, W. F. 1996. Selective activation of effector pathways by brain-specific $\mathrm{G}$ protein beta5. J Biol Chem, 271, 33575-9. 


\section{Figure Legends}

Figure 1: RGS6 has numerous neuropsychiatric, physiological, and pathophysiological roles

This diagram highlights the many neuropsychiatric, physiological and pathophysiological functions that have been attributed to RGS6 as well as the primary literature describing these functions.

\section{Figure 2: The RGS6 protein sequence is highly conserved across the animal kingdom}

This figure shows a conservation map of the largest RGS6 isoform we previously identified (Chatterjee et al., 2003) in different mammalian species. This isoform is designated RGS6La1(+GGL) as it includes the extended N-terminus found in RGS6 long (RGS6L) isoforms, the GGL domain, as well as the alternative $\alpha 1 \mathrm{C}$-terminal sequence encoded by exons 18 and $\alpha$. Each column within the conservation map represents a single amino acid and conservation of color within a column represents amino acid conservation. When looking at the histogram around the outside of the conservation map, green represents 100\% amino acid conservation whereas grey represents $<100 \%$ conservation.

Figure 3: Predicted protein structure and binding partners for human RGS6 protein isoforms

RGS6 is a member of the R7 subfamily (RGS's $6,7,9,11$ ) distinguished by two additional domains, DEP and GGL, which target these proteins to the membrane (through interaction with R9AP and/or R7BP) and promote their stability (through interaction with $\mathrm{G}_{5}$ ), respectively. In addition to DEP- and GGL-mediated spatial function and regulation, RGS6's cellular roles are 
also likely affected by mRNA splicing and alternative domain inclusion/exclusion. A) Illustration of the 36 RGS6 protein isoforms encoded by RGS6 mRNA splice variants we identified (Chatterjee et al., 2003). RGS6 proteins possess either long (RGS6L) or short (RGS6S) Nterminal domains, an incomplete or intact GGL domain, and 9 alternative C-terminal sequences. B) Sequence alignment of the N-terminal region of RGS6 to that of RGS7, RGS9 and RGS11. The grey box represents a region of low sequence conservation that was used to develop the RGS6L antibody, RGS6-L. C) The protein sequence of an alternatively spliced region of RGS6 present in the C-terminus of 56\% of RGS6 protein isoforms that was used to develop RGS6-18 antibody. The approximate location at which the RGS6-L and RGS6-18 antibodies bind to RGS6 proteins is denoted in (A) by an antibody icon.

Figure 4: RGS6 antibodies confirm in vivo RGS6L expression and identify novel RGS6 protein bands

A) Western blots of whole brain lysates derived from RGS6 ${ }^{+/+}(\mathrm{WT})$ and RGS6 ${ }^{-/}$(KO) mice using antibodies against: the whole RGS6L protein (RGS6-fl, left panel), the N-terminus of RGS6L protein isoforms (RGS6-L, middle panel), and an 18 amino acid sequence found in 56\% of RGS6 protein isoforms (RGS6-18, right panel). Magenta arrows represent RGS6 protein bands corresponding in size to RGS6L(+GGL isoforms) (Fig. 4-1). Blue and green arrows represent RGS6 protein bands that are larger $(61$ and $69 \mathrm{kDa})$ than the predicted sizes $(\leq 57 \mathrm{kDa})$ of the RGS6 species we previously identified (Chatterjee et al., 2003). Asterisks represents the RGS7 protein band which is non-specifically recognized by the RGS6-fl and RGS6-18 antibodies. B) Western blot analysis demonstrating that while the RGS6-fl antibody recognizes both RGS6L and RGS6S isoforms overexpressed in HEK cells, the RGS6-L antibody specifically recognizes the RGS6L isoforms. Yellow arrows represent additional RGS6 protein bands produced by overexpression of the RGS6L(+/-GGL) and RGS6S(+/-GGL) vector 
constructs. These bands are smaller than the predicted sizes for the RGS6L(+/-GGL) and RGS6S(+/-GGL) isoforms and likely represent additional protein isoforms produced by novel translation start sites encoded by all constructs (Fig. 4-2). C) Representative western blots from cycloheximide chase experiments characterizing the differential stability of the RGS6L(+/GGL) and RGS6S(+/-GGL) protein isoforms over a 24h period. Yellow arrows represent the additional low molecular weight RGS6 protein bands recognized by the RGS6-fl antibody in panel (B). These bands were not included in the final analysis. D) Densitometric analysis of protein degradation comparing the four RGS6 protein isoforms $(N=3)$ in (C).

\section{Figure 4-1: Predicted molecular weights of known RGS6 isoforms}

This table may be used as a reference for determining the putative identities of RGS6 protein bands present on western blot.

\section{Figure 4-2: Novel putative translation start sites identified within RGS6 protein sequence}

Predicted RGS6La1 protein sequence. Red star denotes alternative start site utilized to produce RGS6S isoforms. Yellow stars denote novel putative translation start sites present in both RGS6L and RGS6S isoforms.

\section{Figure 5: Tissue expression profiling of RGS6 in 31 mouse tissues using the RGS6-L} antibody

Using purified RGS6-L antibody we conducted an analysis of RGS6L expression in 31 tissues throughout the mouse body. A) Representative western blots demonstrating that, in RGS6 ${ }^{++}$ (WT) and RGS6 $+^{{ }^{-}}(\mathrm{H})$ mice compared to $\mathrm{RGS6}^{-{ }^{--}}(\mathrm{KO})$ mice, many CNS and peripheral tissues 
express the 53-57kDa RGS6L(+GGL) protein isoforms (magenta arrow) identified previously (Chatterjee et al., 2003). The blue and green arrows indicate the novel 61 and 69kDa RGS6 protein bands identified in Fig. 4A, and the orange arrow indicates a third novel $65 \mathrm{kDa}$ band identified in the larger expression profile. While the 65 and 69kDa RGS6 protein bands were brain-specific, the $61 \mathrm{kDa}$ band was identified in multiple tissues. Note: this figure was constructed from multiple gels. Therefore, we have placed vertical black lines between tissue samples to denote RGS6 expression levels cannot be directly compared between tissues. B) Densitometric quantitative analysis of the 53-57kDa RGS6L(+GGL) isoforms (Fig 5A, magenta arrow) reveal that they are significantly expressed in CNS tissues as well as peripherally in atrium and bladder. Two-way ANOVA found significant effects of strain $\left(F_{2,258}=143.75, P \leq\right.$ $0.0001)$, tissue $\left(F_{30,258}=44.11, P \leq 0.0001\right)$, and their interaction $\left(F_{59,258}=15.93, P \leq 0.0001\right)$. Data were analyzed via two-way ANOVA with Fisher's LSD post hoc adjustment. Data are presented as mean \pm S.E.M. ${ }^{*} P \leq 0.05,{ }^{* *} P \leq 0.01,{ }^{* * *} P \leq 0.001,{ }^{* * * *} P \leq 0.0001$. $(N=3-8$ $\mathrm{RGS6}^{+/+}$mice, 2-6 RGS6 ${ }^{+/}$mice, and 2-8 RGS6 ${ }^{-/-}$mice). Extended data in Fig. 5-1 compares significant differences in RGS6 expression across tissues in RGS6 ${ }^{+/+}$mice. Fig. 5-2 shows the conservation of an RGS6 SNP in primates. Abbreviations: CTX = cerebral cortex, OFB = olfactory bulb, $\mathrm{MB}=$ midbrain, $\mathrm{CB}=$ cerebellum, $\mathrm{SC}=$ spinal cord, Ret $=$ retina, $\mathrm{WAT}=$ white adipose tissue, BAT $=$ brown adipose tissue, Ofat $=$ Omental fat, $\mathrm{Spl}=$ spleen, Thy $=$ thymus Pros $=$ prostate, Test $=$ testis, Brst $=$ breast, $\mathrm{Ov}=$ ovary, $\mathrm{Ut}=$ uterus, Atr $=$ atrium, Vent $=$ ventricle, Dia $=$ diaphragm, $\mathrm{Sk}$ mus $=$ skeletal muscle, Eso $=$ esophagus, Stom $=$ stomach, $\mathrm{S}$ int = small intestine, $\mathrm{L}$ int $=$ large intestine, Panc $=$ pancreas, Kid $=$ kidney, $\mathrm{Ad} \mathrm{gl}=$ adrenal gland, Blad $=$ bladder, Plat $=$ platelet

Figure 5-1: Comparison of RGS6 expression across 31 mouse tissues using the RGS6-L antibody. 
Using the RGS6 ${ }^{+/+}$(WT) tissue data from Figure 5, we have graphed RGS6 protein expression detected with the RGS6-L antibody across the same 31 tissues. Here, we find that RGS6 is most highly expressed in the cerebral cortex $(C T X, P \leq 0.000)$ relative to all other tissues tested. Data are represented as mean \pm S.E.M. Data were analyzed via one-way ANOVA with Fisher's LSD post-hoc adjustment. Table below displays the $P$ values of all comparisons of RGS6 expression across the various tissues. Abbreviations: $\mathrm{CTX}=$ cerebral cortex, OFB $=$ olfactory bulb, $\mathrm{MB}=$ midbrain, $\mathrm{CB}=$ cerebellum, $\mathrm{SC}=$ spinal cord, Ret $=$ retina, $\mathrm{WAT}=$ white adipose tissue, BAT $=$ brown adipose tissue, Ofat $=$ Omental fat, $\mathrm{Spl}=$ spleen, Thy $=$ thymus, Pros $=$ prostate, Test $=$ testis, Brst $=$ breast, $\mathrm{Ov}=$ ovary, $\mathrm{Ut}=$ uterus, Atr $=$ atrium, Vent $=$ ventricle, Dia = diaphragm, Sk mus = skeletal muscle, Eso = esophagus, Stom $=$ stomach, $\mathrm{S}$ int $=$ small intestine, $\mathrm{L}$ int $=$ large intestine, Panc $=$ pancreas, Kid $=$ kidney, $\mathrm{Ad}$ gl $=$ adrenal gland, $\mathrm{Blad}=$ bladder, Plat $=$ platelet

Figure 5-2: Evolutionary conservation of the rs2332700 SNP.

Human RGS6 sequence (37bps) flanking the rs2332700 SNP (G>C) aligned against the corresponding sequence present in 30 different animal species across the animal kingdom using the UCSC Genome Browser. The SNP is only found in primates. "=": gap regions in genomes, in which aligning species has one or more unalignable bases. This is likely due to excessive evolutionary distance between the aligning species and human or due to independent insertions/deletions in the region between the aligning species and human.

\section{Figure 6: Immunohistochemical analysis of RGS6 tissue distribution}

Representative images from an immunohistochemical analysis of RGS6 protein distribution, using the RGS6-fl antibody, in mouse RGS6 ${ }^{+/+}$(WT) CNS (Left panel) and peripheral (Right 
panel) tissues shown to express RGS6 protein bands via western (Fig. 5A). Complimentary tissues collected from RGS6 ${ }^{-1-}(\mathrm{KO})$ controls confirmed that the RGS6-fl antibody, while it recognizes RGS7 via western blots (Fig. 4A), is specific for RGS6 in tissue sections.

Figure 7: Prediction of RGS6La1 phosphorylation sites and identification of a novel, -65kDa brain-specific RGS6 phosphoprotein

A) Putative phosphorylation sites within the RGS6La1 protein were identified using the GPS 3.0 software (Fig. 7-1). Sites with the highest prediction score were mapped to the RGS6La1 protein sequence with the corresponding kinase labeled. Serine residues are indicated in blue, threonine in pink, and tyrosine in green. B) A representative western blot from RGS6 ${ }^{++}$(WT) and $\mathrm{RGS6}^{-{ }^{-}}(\mathrm{KO})$ brain tissue lysates treated where indicated with $\lambda$ phosphatase. The magenta arrow indicates the $\sim 53-57 \mathrm{kDa}$ RGS6L(+GGL) isoforms, while the blue, orange, and green arrows indicate the novel RGS6 protein bands $(61,65$, and $69 \mathrm{kDa}$, respectively) identified in this study. C) A densitometric quantification of the $56 \mathrm{kDa}, 61 \mathrm{kDa}, 65 \mathrm{kDa}$, and $69 \mathrm{kDa}$ RGS6 protein bands (B). Two-way ANOVA with Fisher's LSD post-hoc adjustment revealed a significant effect of $\lambda$ phosphatase on the expression of the $65 \mathrm{kDa}(P \leq 0.0001)$ and $69 \mathrm{kDa}(P \leq$ 0.0001 ) bands relative to their respective untreated samples. Data are presented as mean \pm S.E.M. ${ }^{\star \star \star \star} P \leq 0.0001$. ( $N=3$ mice per treatment). D) A representative western blot from $\mathrm{RGS6}^{+/+}(\mathrm{WT})$ and $\mathrm{RGS6}^{-{ }_{-1}}(\mathrm{KO})$ brain tissue lysates treated where indicated with PMA (200nM), cAMP and Forskolin $\left(10 \mu \mathrm{M}\right.$ of each), or $\mathrm{Ca}^{2+}(10 \mu \mathrm{M})$. E) A densitometric quantification of the 56kDa, 61kDa, 65kDa, and 69kDa RGS6 protein bands (D). Two-way ANOVA with Fisher's LSD post-hoc adjustment found a significant effect of $\mathrm{Ca}^{2+}$ treatment on the expression of the $65 \mathrm{kDa}(P \leq 0.0001)$ and $69 \mathrm{kDa}(P=0.002)$ bands relative to their respective untreated samples. 
Figure 7-1: Putative phosphorylation sites in the RGS6La1 protein

$\mathrm{X}$ denotes sites that were also predicted by PhosphoNet or have been confirmed as phosphorylated residues through mass spectrometry data sets.

Figure 8: The 69kDa brain-specific RGS6 protein band is highly conserved and significantly expressed in all mouse CNS tissues analyzed

A) Densitometric quantification of the $69 \mathrm{kDa}$, brain-specific RGS6 protein band (Fig. 5A, green arrow) demonstrates that it is significantly expressed in all RGS6 ${ }^{+/+}$(WT) mouse brain tissues, compared to RGS6 ${ }^{+-}(\mathrm{H})$ and RGS6 ${ }^{--}(\mathrm{KO})$ tissues analyzed. Two-way ANOVA found significant effects of strain $\left(F_{2,32}=99.51, P \leq 0.0001\right)$, tissue $\left(F_{4,32}=21.19, P \leq 0.0001\right)$, and their interaction $\left(F_{8,32}=21.19, P=0.000\right)$. Data were analyzed via two-way ANOVA with Fisher's LSD post hoc adjustment. Data are presented as mean \pm S.E.M. ${ }^{*} P \leq 0.05,{ }^{*} P \leq 0.01$, ${ }^{\star * \star} P \leq 0.001,{ }^{* * *} P \leq 0.0001$. ( $N=3-4 \mathrm{RGS6}^{+/+}$mice, 2-3 RGS6 ${ }^{+/-}$mice, and 3-4 RGS6 ${ }^{-/-}$mice $)$.

Extended data in Fig. 8-1 compares significant differences in RGS6B expression across tissues in $\mathrm{RGS6}^{+/+}$mice. Abbreviations: $\mathrm{CTX}=$ cerebral cortex, $\mathrm{CB}=$ cerebellum, $\mathrm{MB}=$ midbrain, $\mathrm{SC}$ = spinal cord, OFB = olfactory bulb. B) Western blot analysis of mouse and human brain lysates indicate that the 61 and $69 \mathrm{kDa}$, brain-specific protein bands (blue and green arrows, respectively) are conserved in mouse and human.

Figure 8-1: Comparison of RGS6B expression across CNS mouse tissues using the RGS6-L antibody.

Using the RGS6 ${ }^{+/}$(WT) tissue data from Fig. 8, we have graphed RGS6B protein expression detected with the RGS6-L antibody across mouse CNS tissues. Data are represented as mean 
\pm S.E.M. Data were analyzed via one-way ANOVA with Fisher's LSD post-hoc adjustment. Table below displays the $P$ values of all comparisons of RGS6 expression across the various tissues. Abbreviations: $\mathrm{CTX}=$ cerebral cortex $\mathrm{CB}=$ cerebellum, $\mathrm{MB}=$ midbrain, $\mathrm{SC}=$ spinal cord, OFB = olfactory bulb.

Figure 9: RGS6 is the only R7 family member expressed in bladder, lung, omental fat, stomach, and intestine

A) Densitometric quantification of $G \beta_{5}$ expression in tissues shown to express RGS6 protein bands via western (Fig. 5A). Inset: Structure homology modeling of RGS6La2 in complex with $G \beta_{5}$. Two-way ANOVA found significant effects of strain $\left(F_{2,135}=19.69, P \leq 0.0001\right)$ and tissue $\left(F_{15,135}=90.64, P \leq 0.0001\right)$. Data were analyzed via two-way ANOVA with Fisher's LSD post hoc adjustment. Data are presented as mean \pm S.E.M. ${ }^{\star} P \leq 0.05,{ }^{* \star} P \leq 0.01,{ }^{* \star} P \leq 0.001$, ${ }^{\star \star \star \star} P \leq 0.0001 .\left(N=2-6 \mathrm{RGS6}^{+/+}\right.$mice, 2-5 $\mathrm{RGS6}^{+/-}$mice, and 3-6 RGS6 ${ }^{-/-}$mice $)$. Extended data in Fig. 9-1 compares significant differences in $\mathrm{G} \beta_{5}$ expression across tissues in RGS6 ${ }^{+/+}$ mice. Abbreviations: $\mathrm{CTX}=$ cerebral cortex, $\mathrm{CB}=$ cerebellum, $\mathrm{MB}=$ midbrain, $\mathrm{SC}=$ spinal cord, OFB = olfactory bulb, Ret $=$ retina, Ofat $=$ Omental fat, Atr $=$ atrium, Vent $=$ ventricle, Brst $=$ breast, Stom $=$ stomach, $\mathrm{S}$ int $=$ small intestine, $\mathrm{L}$ int $=$ large intestine, $\mathrm{Kid}=$ kidney, Blad $=$ bladder. B) Representative western blot analysis of a subset of the tissues from (A) showing a concomitant loss of RGS6 and $G \beta_{5}$ expression using antibodies against the individual R7 family members confirmed that RGS6 is the only R7 member expressed there. Note: The G⿰氵 5 portion of this figure was constructed from multiple blots. Therefore, we have placed vertical black lines between $\mathrm{G} \beta_{5}$ tissue samples to denote expression levels cannot be directly compared. The first lane labeled "WT" is a lysate from whole brain for all blots except for the blot for RGS9-2, where it is striatum, as RGS9-2 is not detectable in whole brain lysates (Luo et al., 2019).

Abbreviations: $\mathrm{WT}=\mathrm{RGS6}^{+/+}, \mathrm{H}=\mathrm{RGS6}^{+/-}$, and $\mathrm{KO}=\mathrm{RGS6}^{-/-}$. 
1016

1017 Figure 9-1: Comparison of $\mathrm{G} \beta_{5}$ expression across 16 mouse tissues.

1018 Using the RGS6 ${ }^{+/}$(WT) tissue data from Fig. 9, we have graphed Gß5 protein expression

1019 across 16 mouse tissues. Data are represented as mean \pm S.E.M. Data were analyzed via

1020 one-way ANOVA with Fisher's LSD post-hoc adjustment. Table below displays the $P$ values of

1021 all comparisons of RGS6 expression across the various tissues. Abbreviations: CTX =

1022 cerebral cortex, $\mathrm{CB}=$ cerebellum, $\mathrm{MB}=$ midbrain, $\mathrm{SC}=$ spinal cord, $\mathrm{OFB}=$ olfactory bulb, Ret $=$

1023 retina, Ofat $=$ Omental fat, Atr $=$ atrium, Vent $=$ ventricle, Brst $=$ breast, Stom $=$ stomach, $\mathrm{S}$ int $=$ 1024 small intestine, $\mathrm{L}$ int $=$ large intestine, $\mathrm{Kid}=$ kidney, Blad $=$ bladder . 
Pleiotropic Mechanisms Across Four Psychiatric Disorders Cross-Disorder Group of the Psychiatric Genomics Consortium, Cell, 2019

Alzheimer's Disease Moon et al., J Alzheimer's Dis, 2015

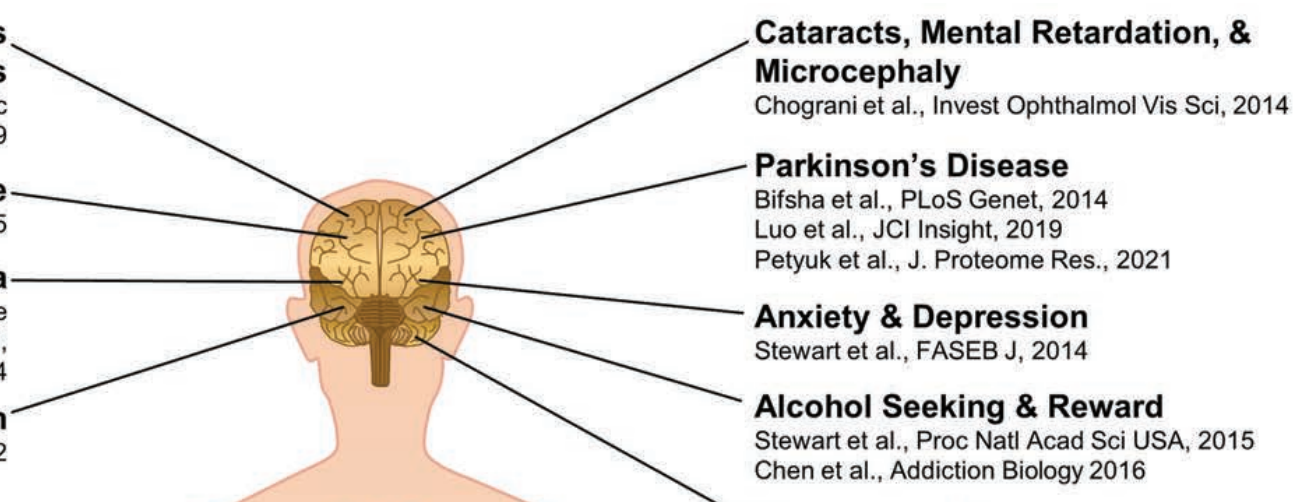

Schizophrenia Working Group of the Psychiatric Genomics Consortium, Nature, 2014

Motor Coordination Maity et al., JBC, 2012

Heart Ischemic Injury Ther, 2017

Heart Parasympathetic Activity Yang et al., Circ Res, 2010 Poshokova et al., Circ Res, 2010 Wydeven et al., JBC, 2014

Breast Cancer
Maity et al. J Biol Chem, 2011 Huang et al., Cancer Res, 2011 Maity et al., Carcinogenesis, 2013 Pancreatic Cancer
Int J Clin Exp Path, 2014 Colorectal Cancer Yang et al., Biomed Pharmacother, 2015

Bladder Cancer

Berman et al., Cancer Res, 2004

Yang et al., Oncotarget, 2016

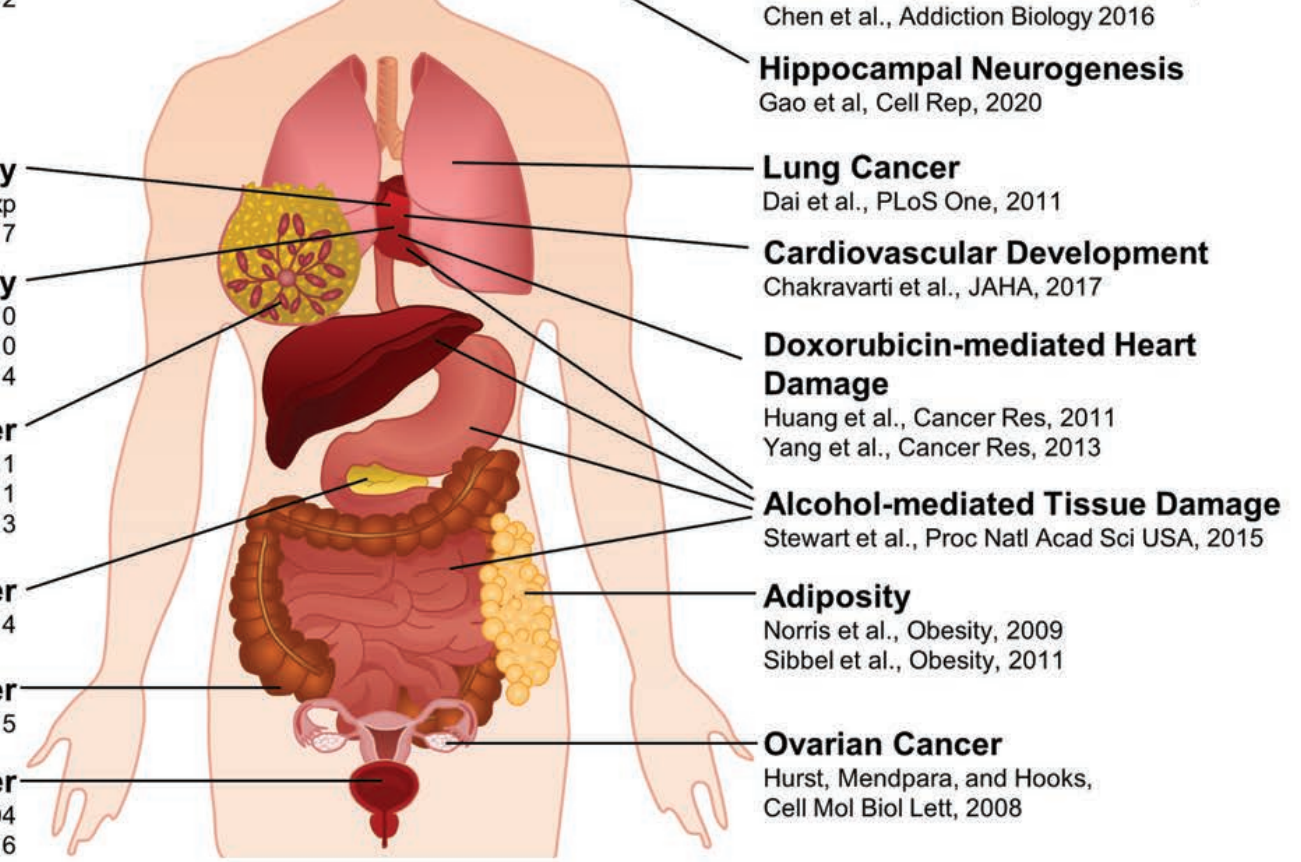




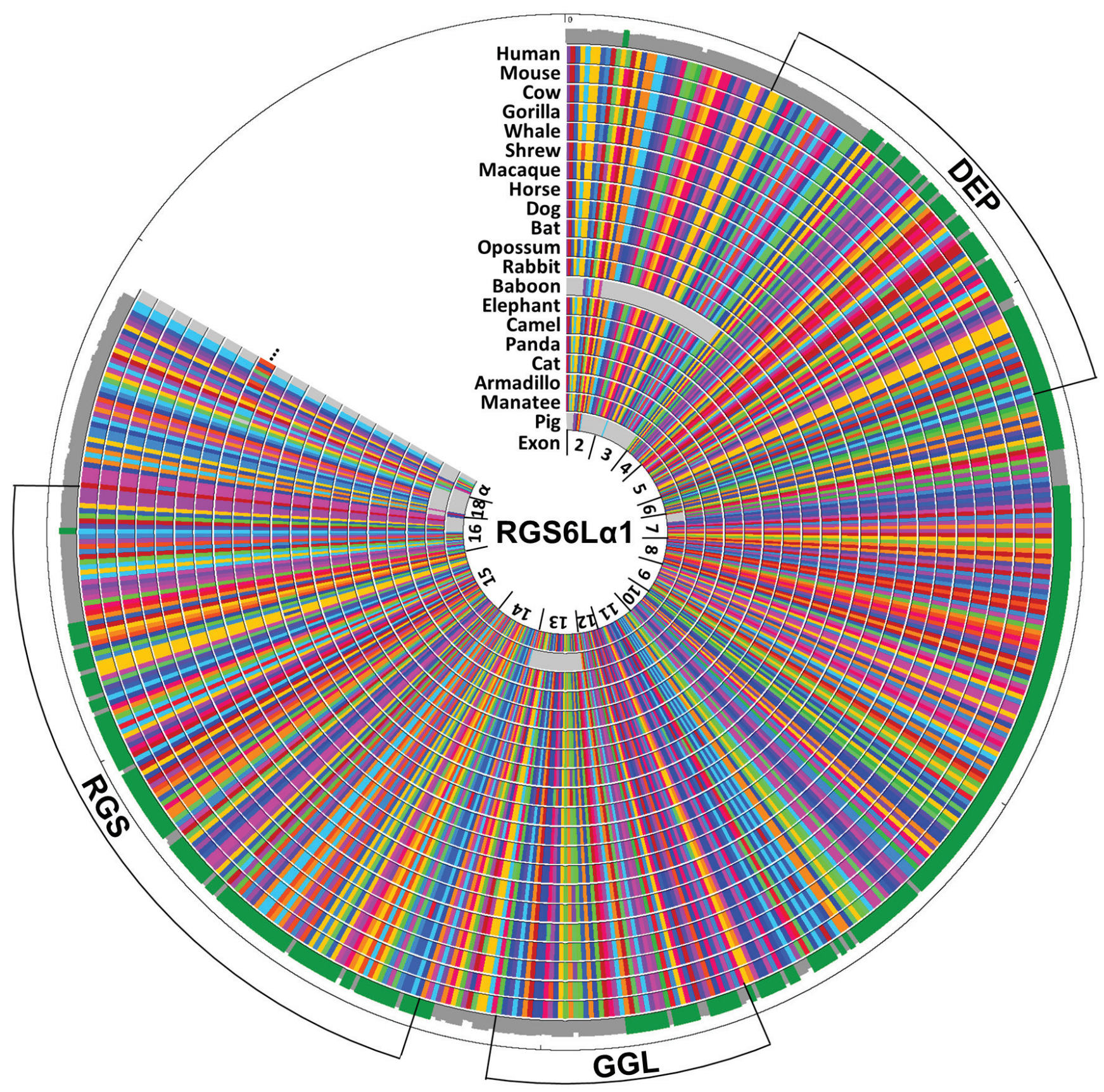


A $\quad$ RGS6-18

B

RGS

RGS6 : MAQGSGDQRAVGVADPEESSPNMIVYCKIED... RGS7 : MAQGNN--YGQTSNGVADESPNMLVYRKMED... RGS9 : MTI--R-------HQGQQYRPRMAFLQKIEA... RGS11: MAAGPA-------PPPGRPRAQMPHLRKMER...

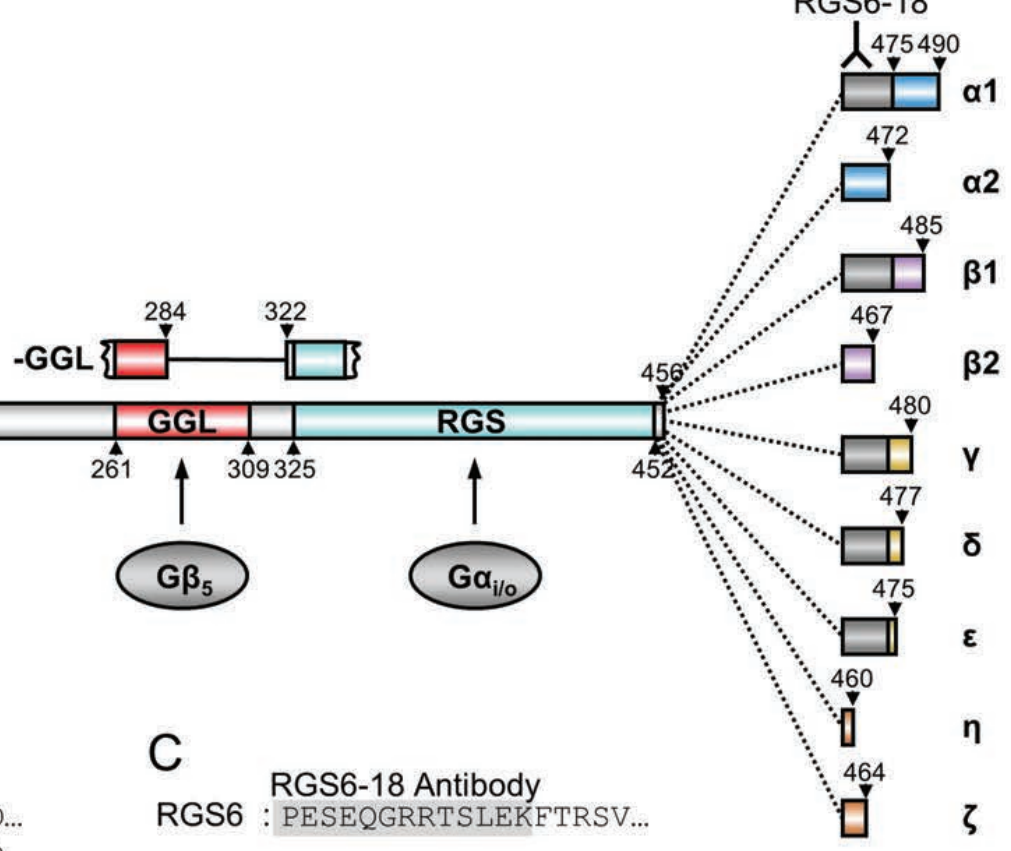




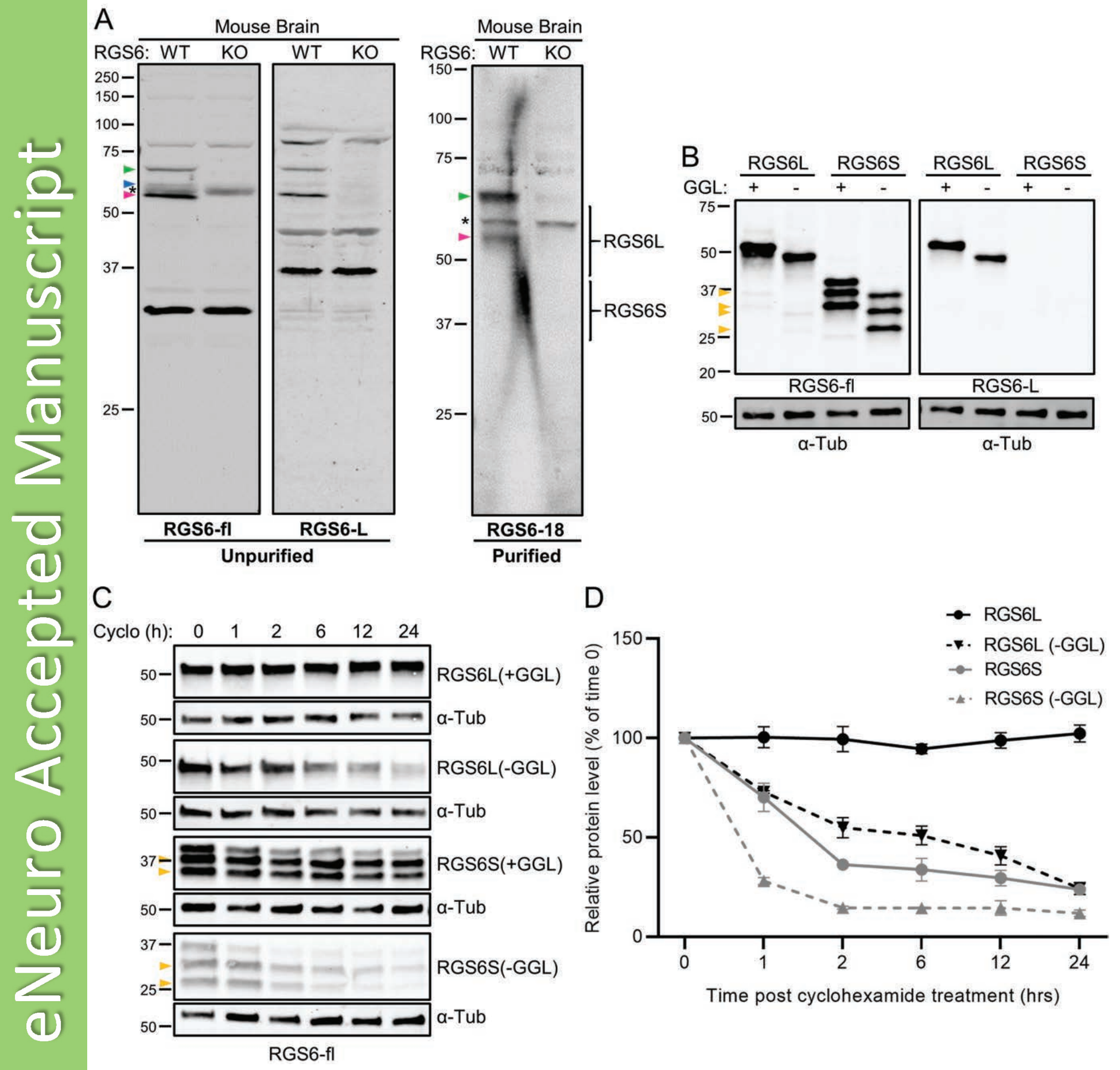


A

Cortex Cerebellum Midbrain Spinal cord Olfactory bulb Retina $\quad$ WAT RGS6 WT WT H KO WT H KO WT H KO WT H KO WT H KO $\overline{\text { WT H KO WT H KO WT H KO }}$

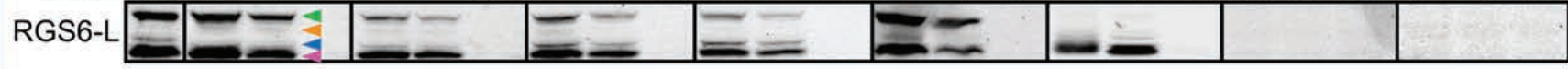

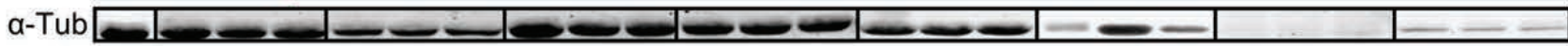

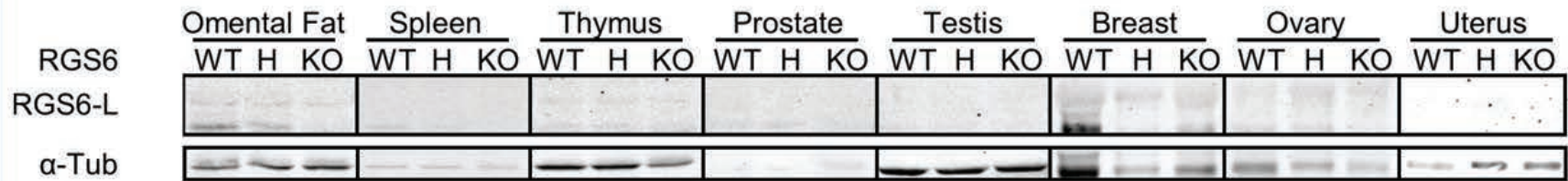

Atrium Ventricle Diaphragm Skel Musc Esophagus Stomach S Intestine LIntestine RGS6 $\overline{\text { WT H KO }} \overline{\text { WT H KO WT H KO WT H KO WT H KO WT H KO WT H KO WT H KO }}$ RGS6-L $\alpha-T u b$ \begin{tabular}{|l|l|l|l|l|l|l|l|}
\hline- & & & & & & & \\
\hline
\end{tabular}

B

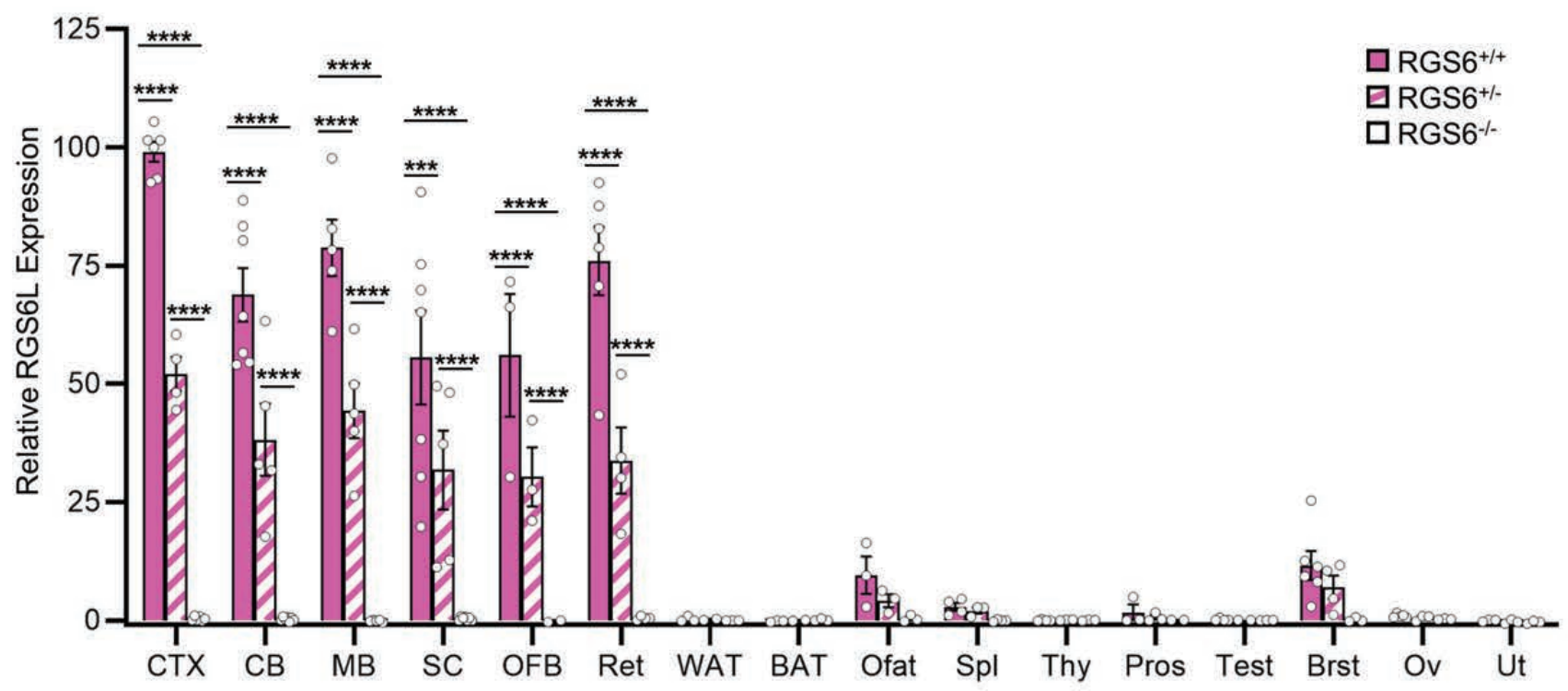

RGS6

RGS6-L

$a-T u b$

Lung Liver Pancreas Kidney Adr Gland Bladder Platelet $\overline{\text { WT H KO }} \overline{\text { WT H KO }} \overline{\text { WT H KO }} \overline{\text { WT H KO }} \overline{\text { WT H KO }} \overline{\text { WT H KO }} \overline{\text { WT H KO }}$

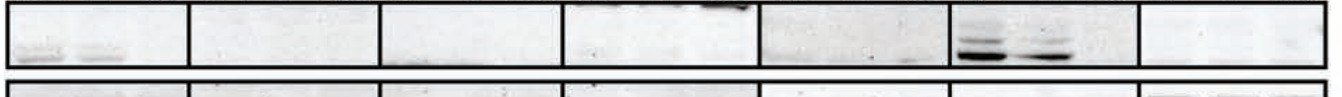

a-Tub

$\square=$

1

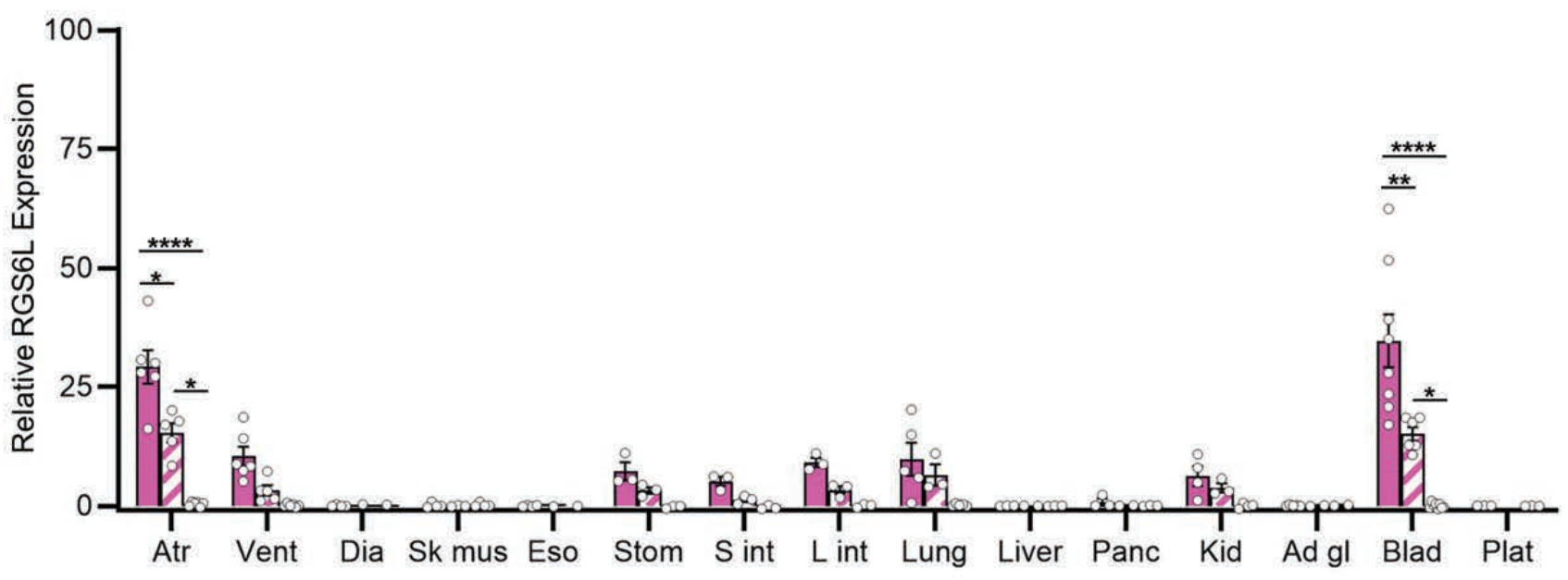


A
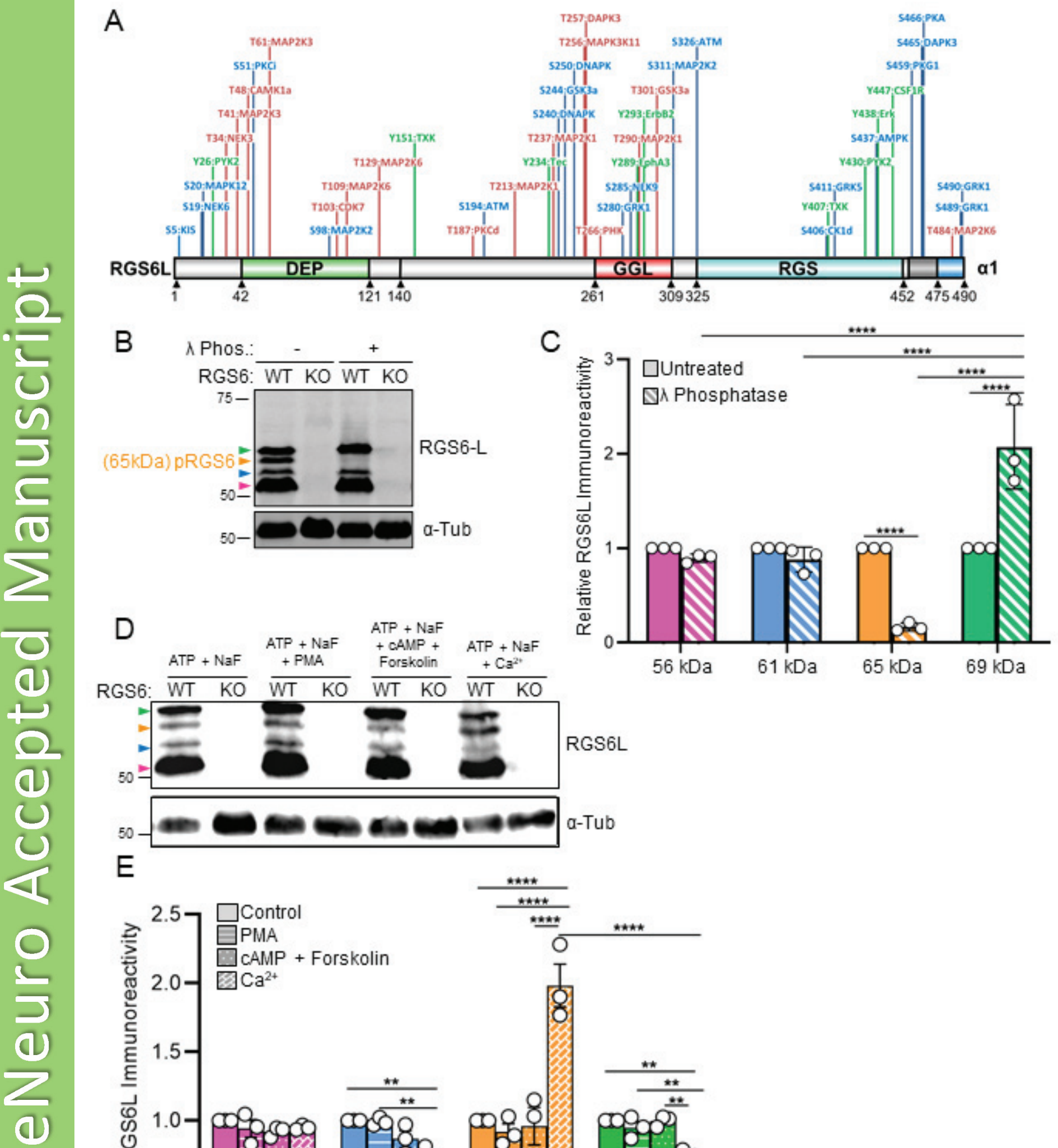

E

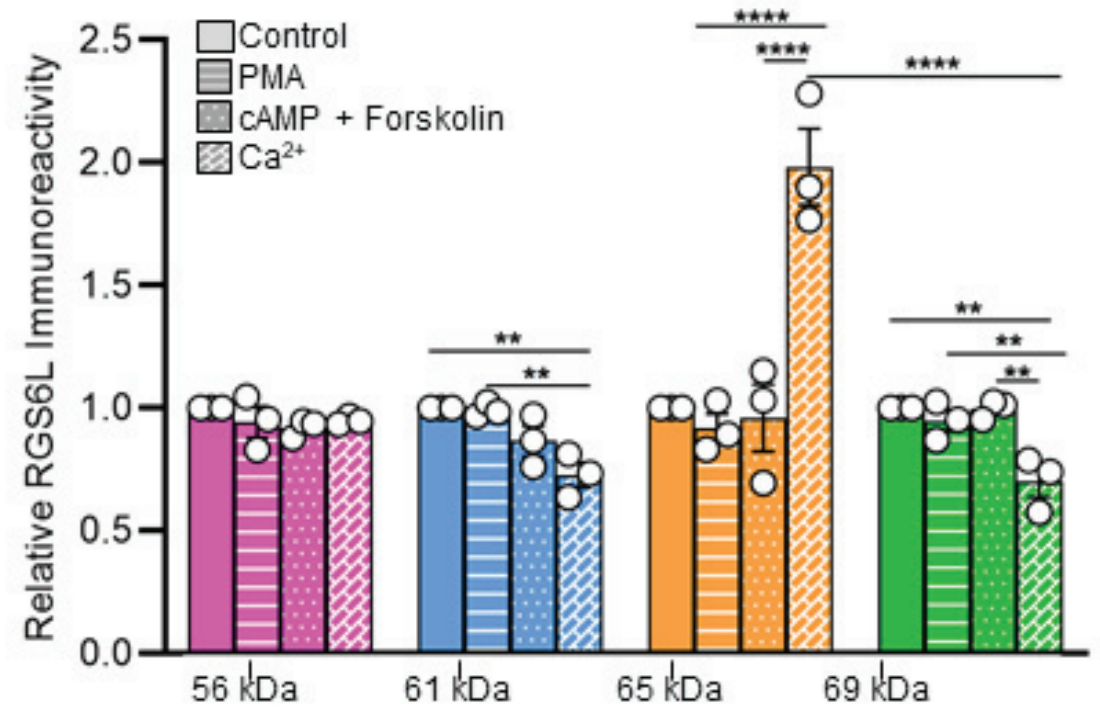




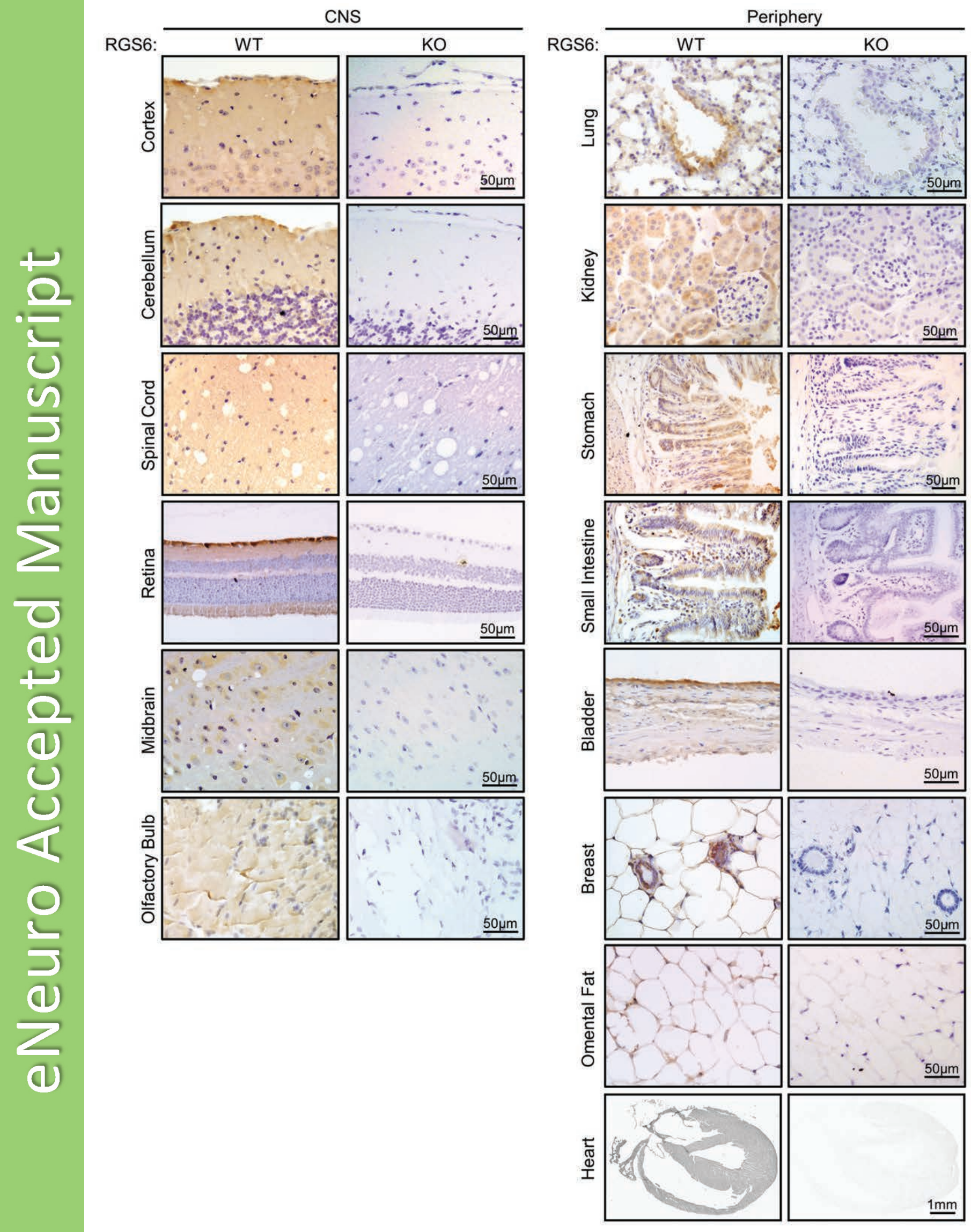




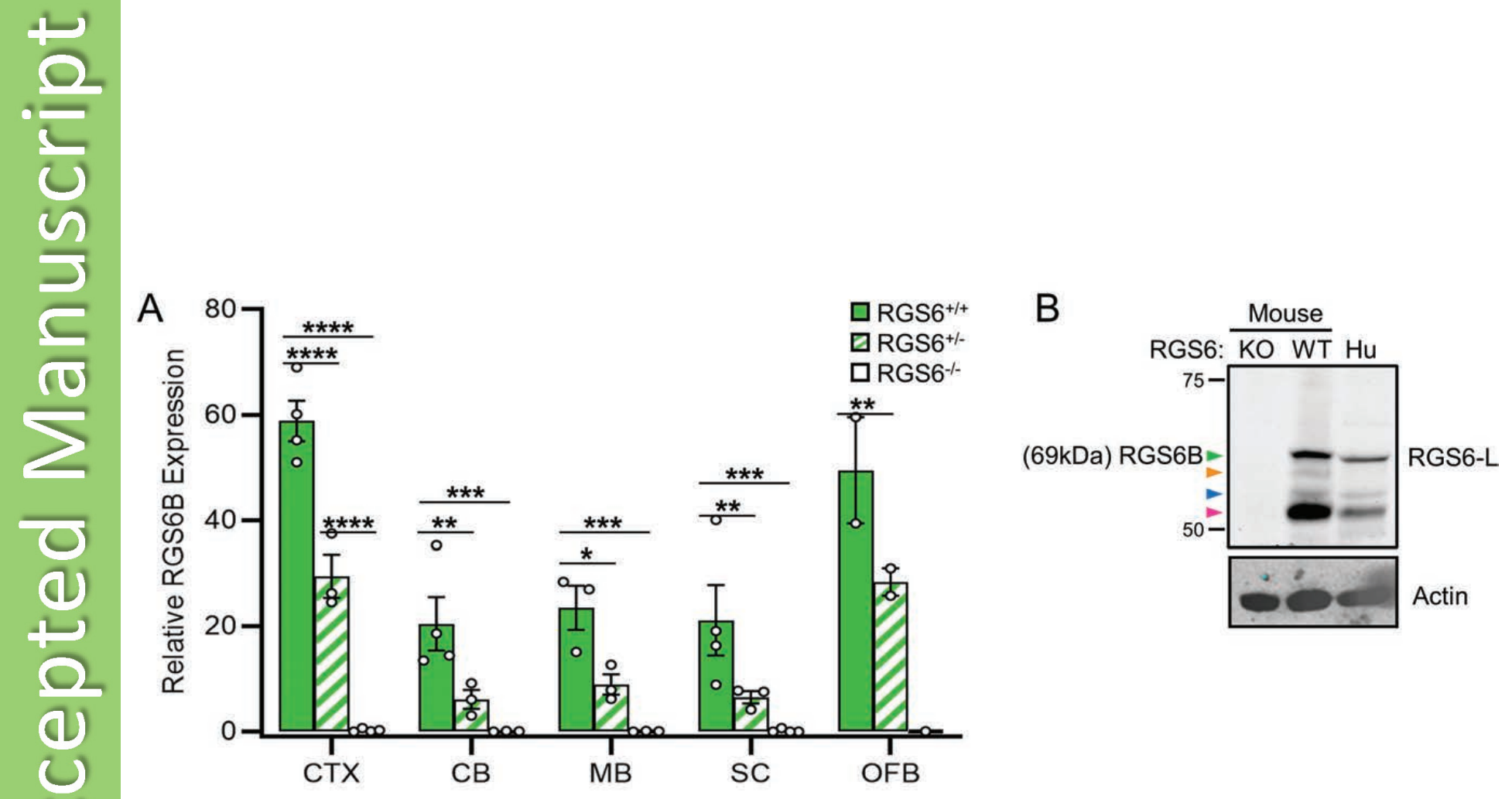




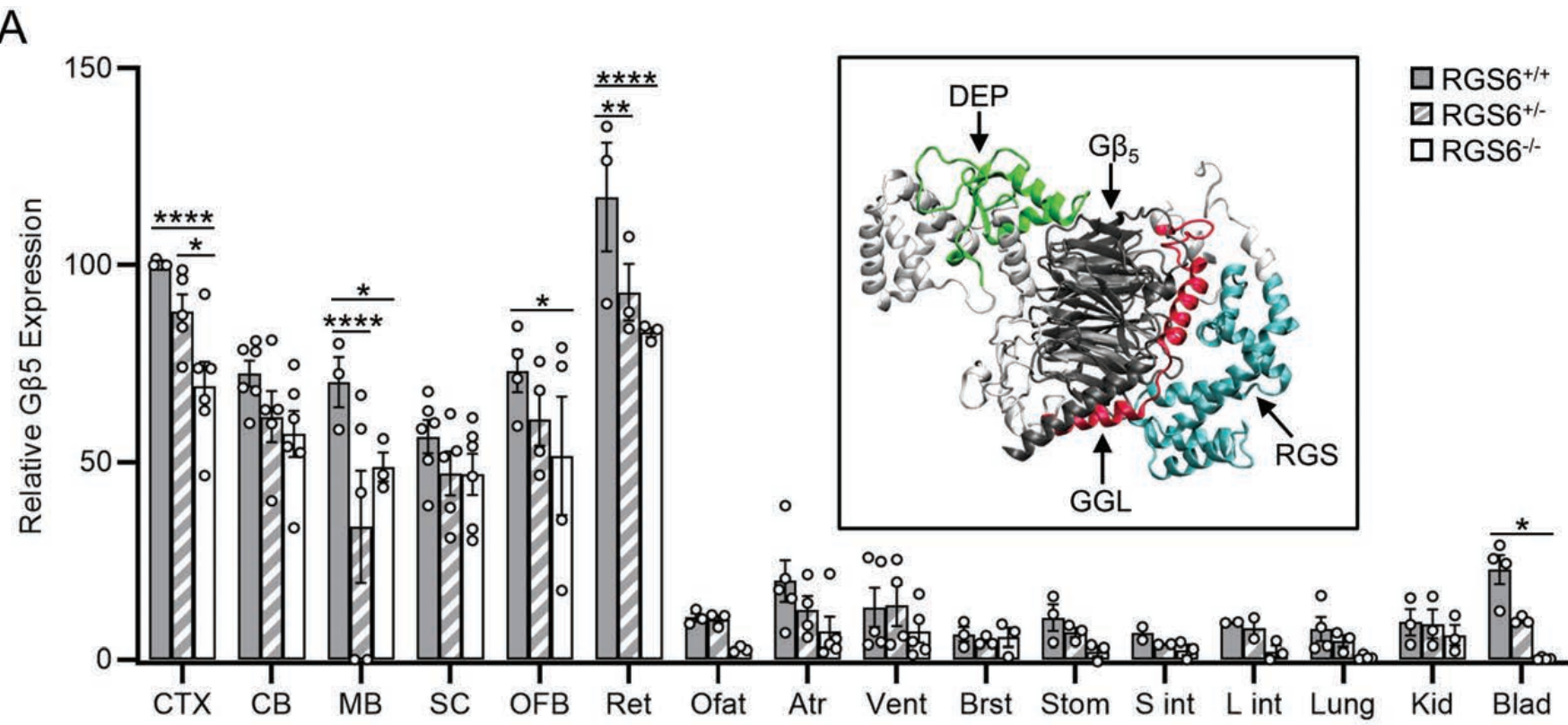

B

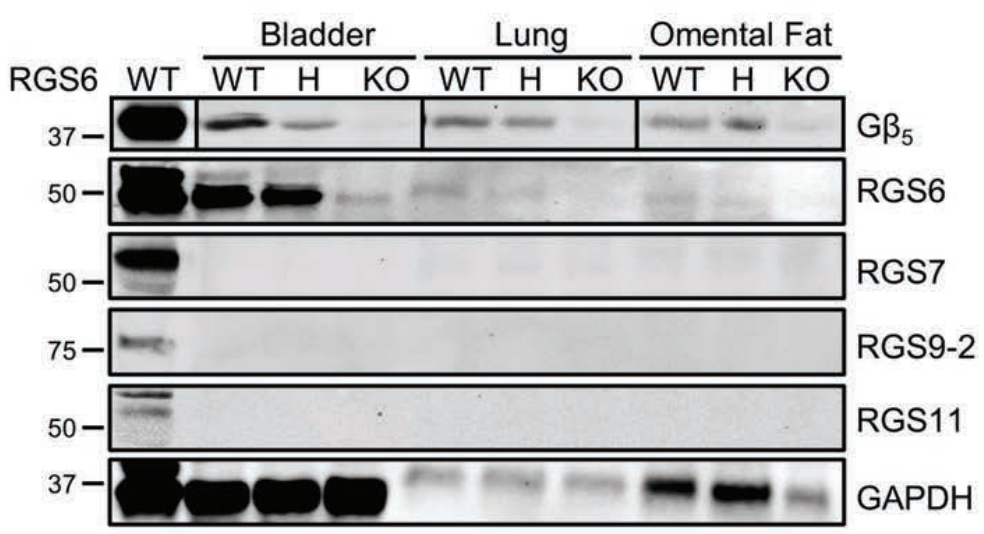

